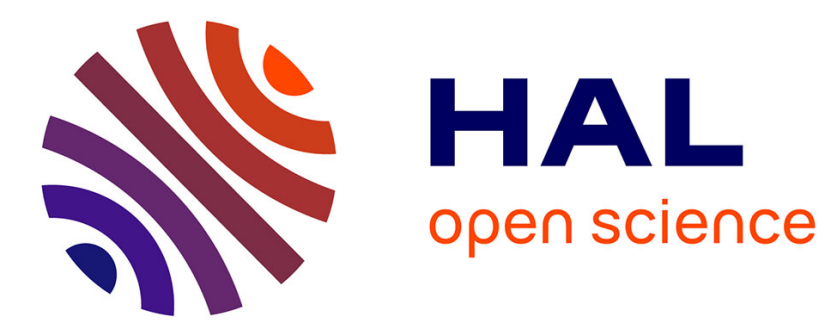

\title{
"Iridium effect" in cyclometalated iridium complexes for p-type dye sensitized solar cells
}

Odobel Fabrice, Florent Légalité, Daniel Escudero, Yann Pellegrin, Errol

Blart, Denis Jacquemin, Fabrice Odobel

\section{- To cite this version:}

Odobel Fabrice, Florent Légalité, Daniel Escudero, Yann Pellegrin, Errol Blart, et al.. "Iridium effect" in cyclometalated iridium complexes for p-type dye sensitized solar cells. Dyes and Pigments, 2019, 171, pp.107693. 10.1016/j.dyepig.2019.107693 . hal-03017382

\section{HAL Id: hal-03017382 \\ https://hal.science/hal-03017382}

Submitted on 20 Nov 2020

HAL is a multi-disciplinary open access archive for the deposit and dissemination of scientific research documents, whether they are published or not. The documents may come from teaching and research institutions in France or abroad, or from public or private research centers.
L'archive ouverte pluridisciplinaire HAL, est destinée au dépôt et à la diffusion de documents scientifiques de niveau recherche, publiés ou non, émanant des établissements d'enseignement et de recherche français ou étrangers, des laboratoires publics ou privés. 


\title{
"Iridium effect" in cyclometalated iridium
}

\section{complexes for p-type dye sensitized solar cells}

Florent Légalité, ${ }^{a}$ Daniel Escudero, ${ }^{b}$ Yann Pellegrin, ${ }^{a} *$ Errol Blart, ${ }^{a}$ Denis Jacquemin,${ }^{a}$ and Fabrice Odobel ${ }^{a, *}$

${ }^{a}$ CEISAM, Chimie Et Interdisciplinarité, Synthèse, Analyse, Modélisation ; CNRS, UMR

CNRS 6230, UFR des Sciences et des Techniques ; 2, rue de la Houssinière - BP 92208;

44322 NANTES Cedex 3 France.

${ }^{\mathrm{b}}$ Department of Chemistry, KU Leuven, Celestijnenlaan 200F, B-3001 Leuven, Belgium.

\begin{abstract}
Cyclometallated iridium complexes have shown great promises as photosensitizers for $\mathrm{p}$-type dye sensitized solar cells (p-DSSC), in particular due to the occurrence of very long-lived interfacial charge separated states, leading to high open circuit potentials (Voc). To rationalize this experimental fact, we prepared a new series of iridium photosensitizers specially designed for $\mathrm{NiO}$ based $\mathrm{p}$-DSSC, in order to assess the role of a panel of factors on the overall photovoltaic performances. We probed the electronic coupling between the iridium complex and the semi-conductor at the level of the anchor, the importance of the frontier orbitals distribution over the photosensitizers structures and the impact of iridium(III) vs. a lighter metal ion like ruthenium(II). The synthesis and full characterizations of these new photosensitizers are presented, and their performances within p-type DSSC are given and discussed in light of their structures. A combination of a high spin-orbit coupling and a smart design of the anchoring ligands explains the interesting performances of iridium complexes as photosensitizers for $\mathrm{p}$ DSSC.
\end{abstract}


Key words: p type dye sensitized solar cells; iridium; cobalt electrolyte; nickel oxide

\section{Introduction}

There has been a growing interest in iridium(III) complexes, because they exhibit unique photophysical properties[1-4] that make them particularly well-suited for applications as dyes in organic light emitting devices (OLEDs),[2, 5] biological labelling agents,[6-10] oxygen sensors,[11-13] photocatalysts for hydrogen evolution,[14-17] dye sensitized solar cells (DSSC),[18-29] as well as for the development of molecular photoactive arrays to attain longlived charge separated states.[30, 31] Over the past few years, some of us[23] and others[20, $24,25]$ have developed iridium(III) cyclometalated complexes for applications in $\mathrm{NiO}$ based ptype dye sensitized solar cells (p-DSSCs) and dye sensitized photoelectrosynthetic solar cells (p-DSPECs). Cyclometalated iridium complexes display appealing properties for these applications, because they exhibit: i) a high oxidative power in the excited state, which ensures a large hole injection driving force; ii) an appreciably cathodic reduction potential favoring the dye regeneration with many different redox mediators or catalysts; and iii) they are photostable and endowed with a usually long triplet excited state lifetime in solution owing to the strong spin-orbit coupling (SOC) promoted by Ir center. In a previous work,[23] we have prepared a series of iridium complexes inspired by the famous photosensitizer[1] [Ir(ppy) $2($ phen $)]^{+}$(where ppy and phen stand respectively for phenylpyridine and phenanthroline) which featured interesting properties as sensitizers in p-DSSCs. They led to surprisingly high open circuit voltage (Voc) and long lived charge separated state, consisting of the reduced dye and a hole in $\mathrm{NiO}$ valence band, herein denoted as " $\mathrm{Ir} / \mathrm{NiO}^{+}$". Reaching such performances with simple dyes is unusual, because $\mathrm{NiO}$-based p-DSSC are notoriously known for their very efficient charge recombination processes, first between the hole in $\mathrm{NiO}$ and the electron on the photoreduced dye (the so-called "geminate" charge recombination), and second between the hole in $\mathrm{NiO}$ and the electrons borne by the redox mediators, i.e., interfacial charge recombination.[32-34] There are three possible reasons behind the unusually slow geminate charge recombination with these cyclometalated iridium complexes. The first one is the electronic decoupling between the sensitizer and $\mathrm{NiO}$ valence band due to the presence of a methylene moiety between the anchoring ppy ligand and the phosphonic acid group. Such a weak electronic interaction should certainly slow down the charge recombination reaction. The second one may arise from the presence of a diimine (bipyridine or phenanthroline) as ancillary ligand. This ligand usually 
carries the LUMO orbital of the complex and therefore bears the electron density after hole injection in $\mathrm{NiO}$, which consequently pulls it away from the $\mathrm{NiO}$ surface. The third reason may be related to the formation of a triplet charge separated state ${ }^{3}\left(-\mathrm{Ir} / \mathrm{NiO}^{+}\right)$, that might arise from the proximity of the heavy nucleus iridium. Studies investigating the effect of the spin multiplicity of the charge separated state are scarce, however, there are reports by Wasielewski[35-37] and other groups[38-43] that demonstrate that triplet charge separated states exhibit much longer lifetime than singlet ones, simply because the recombination to the singlet ground state is a spin forbidden process. Moreover, it is worthwhile noting that Sauvage and co-workers[31, 44, 45] as well as others[30, 46] have developed molecular dyads and triads assembled around an iridium complex sensitizer which also lead to long-lived charge separated states (CSS) upon photoexcitation. Aiming at rationalizing the peculiar behavior of our $\mathrm{NiO}$ iridium sensitizers, we have prepared a new series of iridium complexes based on the basic skeleton of model complex Ir1 (Chart 1).

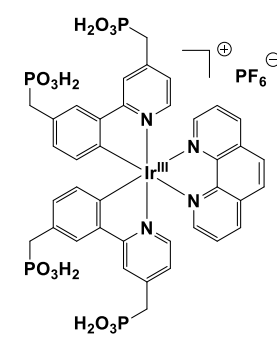

Ir1

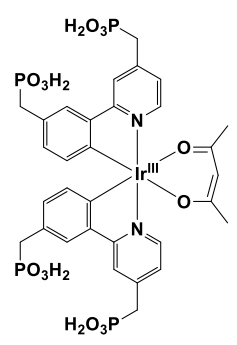

Ir2

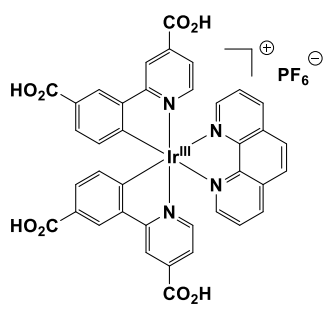

Ir3

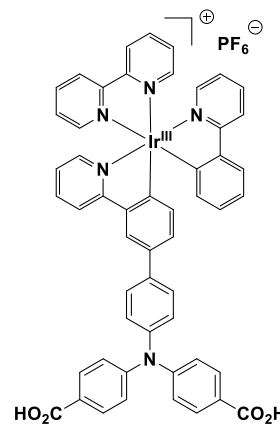

Ir4

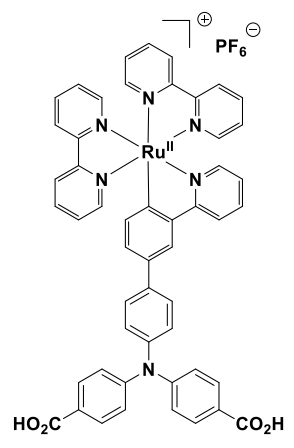

Ru4

Chart 1. Structures of the complexes investigated in this work.

First, we aimed to assess the importance of the methylene spacer between the anchoring group and the ppy ligand. We thus prepared the complex Ir3 where carboxylic acid anchors have been directly tethered to the ppy ligand. Carboxylic acids were chosen instead of phosphonic acid for synthetic comfort; although both acids have different structures, they share a conjugated electron-withdrawing groups with the appended pyridine. Due to the lack of spacing unit, the carboxyl groups in Ir3 are likely to promote higher electronic coupling than the methylene phosphonic acid groups in Ir1. Secondly, the $\pi$-accepting phenanthroline ligand in complex Ir1 was replaced by the electron rich acetylacetonate (acac) in $\mathbf{I r 2}$, with the goal of removing the LUMO from the ancillary ligand and thereby forcing the injected electron to reside on the anchoring ppy ligands. This modification should shed some light on the validity of the second hypothesis. The possible formation of a triplet CSS could be investigated with a parent 
ruthenium cyclometalated complex, because this type of sensitizers is particularly efficient in p-DSSCs[47-50] and ruthenium being lighter than iridium the spin-orbit coupling is weaker. However, a bis-cyclometalated ruthenium complex, that is an analogous structure as that of Ir1 is not suitable for p-DSSC, because it is so electron rich that it is oxidized at very low potential (barely stable in air and displays weak oxidizing power in the excited state: $\mathrm{E}_{\mathrm{Ox}}\left(\mathrm{Ru}(\mathrm{ppy})_{2} \mathrm{bpy}{ }^{\mathrm{III}} / \mathrm{II}\right) \approx-0.3 \mathrm{~V}$ vs SCE).[51, 52] Another way to appreciate the impact of iridium on the overall behavior of the p-DSSC is to prepare a known ruthenium sensitizer with iridium instead and compare their figures of merit, especially their Voc, when implemented in a working device using a cobalt tris-bipyridine based redox mediator. It is well known that polypyridine cobalt(III) complexes are slow electron acceptors owing to high reorganization energy that accompanies reduction.[53] Therefore, polypyridine cobalt(III) complexes are only compatible with $\mathrm{NiO}$ sensitizers leading to a long-lived CSS (microsecond time scale).[33] In this framework, the cyclometalated ruthenium Ru4 published by $\mathrm{Wu}$ and co-workers is an excellent candidate since it is an efficient dye developed for p-DSSC, and most importantly the interfacial CSS is known to be short-lived as determined by the detailed photophysical study published by that group.[48] This prompted us to prepare Ir4, which is a "copy" of Ru4, where the $\mathrm{Ru}(\mathrm{II})$ metal ion has been replaced by $\mathrm{Ir}(\mathrm{III})$ and to compare their performances in p-DSSC (Chart 1). Clearly, its compatibility with the cobalt electrolyte and the production of a large Voc could be considered as strong evidence that it leads to a long-lived CSS. In this contribution, we demonstrate that the peculiar properties of the bis-cyclometalated iridium complexes stem from the combination of the three above -described hypotheses: first the electronic decoupling of the CSS with the ground state through the introduction of a non-conjugated linker, second the localization of the electron in the reduced dye far apart from the $\mathrm{NiO}$ surface, and third the formation of a triplet CSS induced by the presence of iridium.

\section{Results and discussion}

\section{A. Synthesis of the complexes}

The synthesis of the three new iridium complexes Ir2, Ir3, and Ir4 is presented in Scheme 1. The synthesis of $\mathbf{I r} \mathbf{2}$ and $\mathbf{I r} \mathbf{3}$ relies on the same strategy, namely the isolation of iridium dimers 1 and 2,[54-57] and the subsequent coordination with acac and phenanthroline, respectively. Attempts to perform the reactions in apolar solvents (such as 1,2-dichloroethane)[58] were unsuccessful. We thus turned to the more polar solvent methoxyethanol[59] because the higher 
polarity of the reaction medium is known to favor the ligand exchange reactions. Besides, the latter solvent is endowed with a higher boiling point, allowing to increase the reaction temperature and consequently improve the reaction rate. The drawback of this approach is the substantially decreased yields of the coordination reaction (55 and 44\% for Ir2' and Ir3' respectively) because of partial hydrolysis of the ester linkages in these conditions and subsequent loss of compound on silica gel.
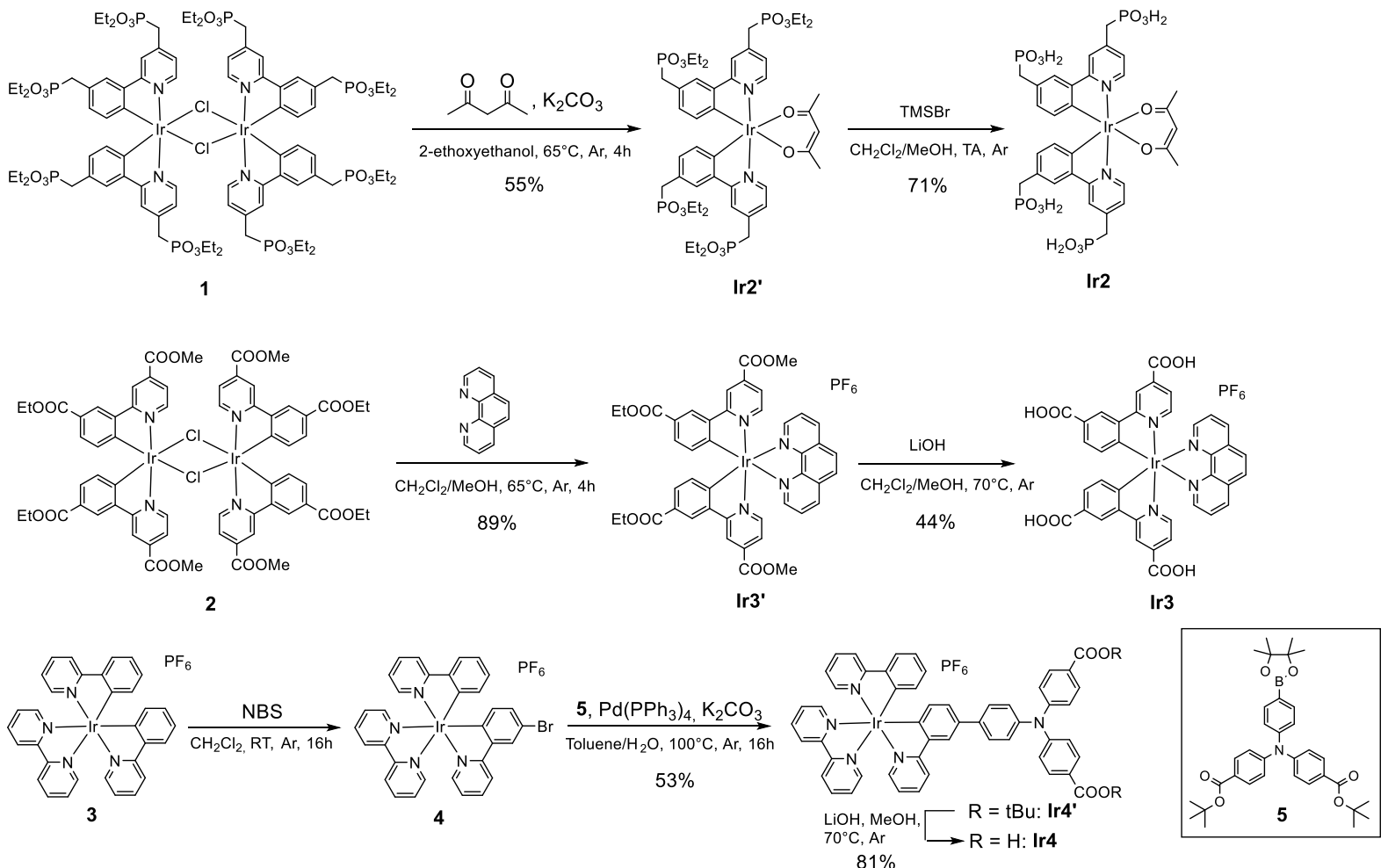

Scheme 1. Synthesis of complexes Ir2, Ir3 and Ir4

Ir4' was prepared via another synthetic route, starting from famous $\left[\operatorname{Ir}(\mathrm{ppy})_{2}(\mathrm{bpy})\right]^{+}$complex (3).[60] Because position 5' of the ppy ligand, once coordinated onto a metal ion is known to exhibit an enhanced reactivity with electrophiles,[61-63] complex 3 was reacted with a substoichiometric amount of NBS. The obtained crude contained a mixture of the desired 5'bromo-substituted complex 4 together with di- and non-substituted complexes. In our hands, the isolation of $\mathbf{4}$ from this mixture proved impossible. Subsequent Suzuki-Miyaura coupling with 5[64] was thus performed on this mixture which proved to be easier to purify by silica chromatography, thanks to the larger polarity differences between the three obtained complexes. Ir4' was obtained in this way with a very satisfactory yield of $53 \%$. 
Hydrolysis of the latter complexes Ir2', Ir3' and Ir4' was then performed in order to isolate pure Ir2, Ir3 and Ir4 photosensitizers. Due to the well-known fragility of the Ir-C bond, base mediated hydrolysis with lithine was preferred over acidic treatment. In the case of Ir2, the hydrolysis of the phosphonic ester groups was complicated by the experienced fragility of the Ir-O bond within Ir-acac coordination sphere. A very mild treatment with TMSBr at room temperature, for a controlled reaction time allowed isolating pure Ir2 with $71 \%$ yield. All complexes were characterized by NMR and high-resolution mass spectrometry. Experimental data fully confirmed the envisioned structures (see experimental part).

\section{B. Electronic UV-visible absorption and emission spectroscopy}

The absorption and emission properties of all dyes were recorded in dichloromethane solution at room temperature and are displayed in Figure 1. For solubility reasons, all the spectroscopic studies were performed on the associated esters Ir1' (structure in figure S1), Ir2', Ir3', Ir4' (scheme 1). The optical data including wavelengths of maximal absorption $\left(\lambda_{\text {abs }}\right)$, extinction coefficients $(\varepsilon)$, wavelength of maximal emission $\left(\lambda_{\mathrm{em}}\right)$ and zero-zero energy level of the lowest singlet excited state $\left(\mathrm{E}_{00}\right)$, are collected in Table 1. The emission lifetime were also determined (Table 2 and Figures S2-S4).

The experimental spectra of Ir3' and Ir4' display the usual spectral signatures of heteroleptic $\left[\operatorname{Ir}(\text { ppy })_{2} \text { (diimine) }\right]^{+}$complexes.[65] They are dominated by broad absorption features between 300 and $400 \mathrm{~nm}$ corresponding to ppy- and diimine-centered $\pi-\pi^{*}$ transitions. In the case of Ir4' an additional, intense absorption band is monitored at $348 \mathrm{~nm}$, assigned to the triphenylamine moiety. Weaker absorption bands (ca. $5000 \mathrm{M}^{-1} . \mathrm{cm}^{-1}$ ) extend above $400 \mathrm{~nm}$, usually attributed to intricate mixtures of ILCT and MLCT (see Section D below) and conferring a yellow hue to those complexes. Importantly, these transitions, albeit of relatively modest intensities, are responsible for the photovoltaic activity of the iridium complexes under AM1.5 simulated irradiation (UV is only ca. $4 \%$ of the total solar irradiance). Accordingly, the light harvesting efficiency of these complexes in the visible is mediocre; in this regard, the case of complex Ir2' is interesting, since it exhibits the longest onset wavelength with a broad absorption feature extending above $500 \mathrm{~nm}$, in agreement with its parent [ $\operatorname{Ir}(\mathrm{ppy})_{2}$ (acac)] complex.[66,67] This is due to the electron-donating nature of the acac ligand that enriches the electron density around the metal ion. Overall, the spectra of $\mathbf{I r 2}$ ' and [Ir(ppy) 2 (acac)] are very similar, due to the small electronic influence of the $\mathrm{CH}_{2}-\mathrm{PO}_{3} \mathrm{Et}_{2}$ moieties on the ppy ligand. 


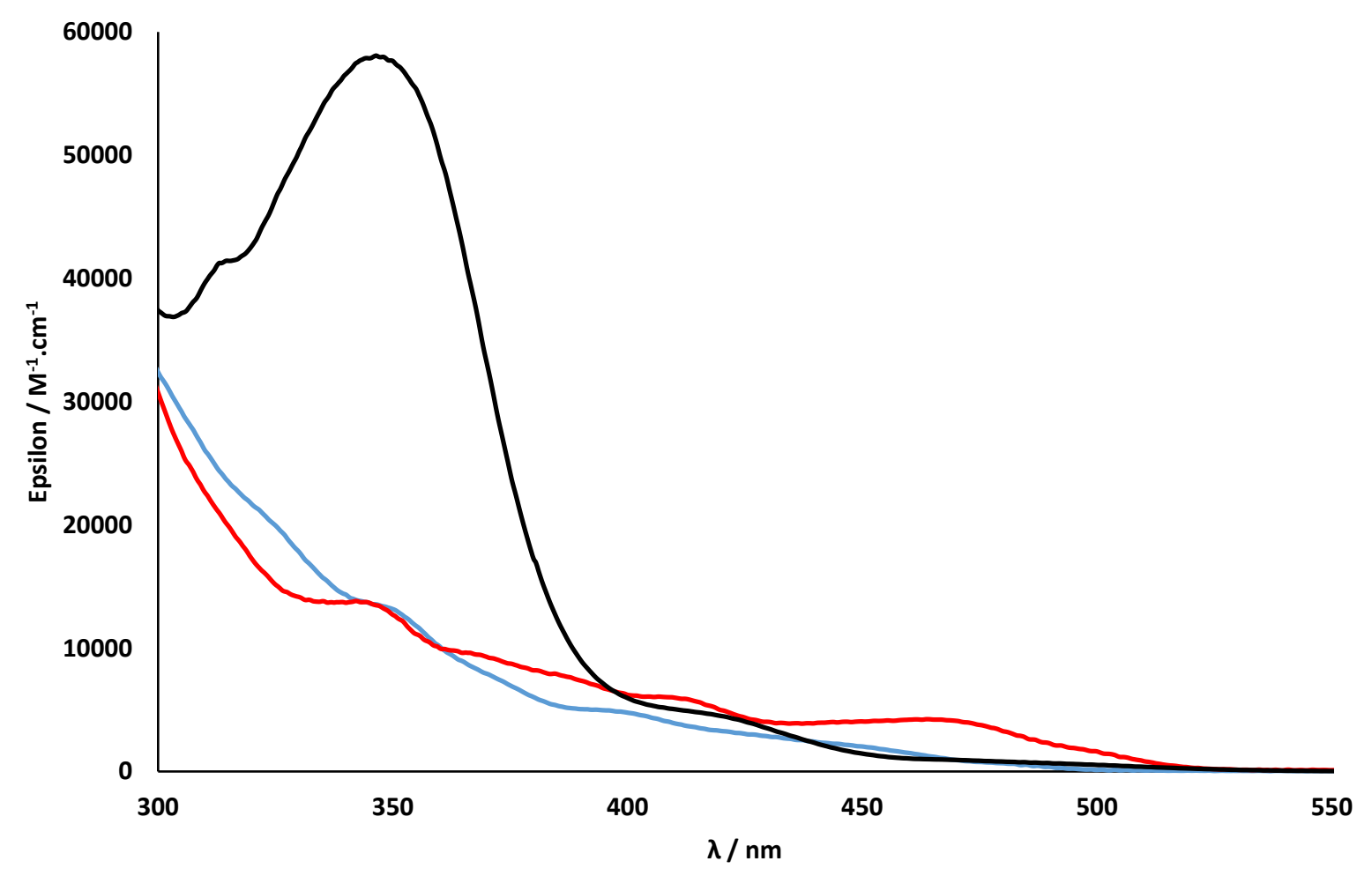

Figure 1. Absorption spectra for complexes Ir2' (red line), Ir3' (blue line) and Ir4' (black line).

Upon excitation in the longest wavelength, all three new complexes in solution display an intense photoluminescence (Figure 2) arising from excited states of predominant ${ }^{3} \mathrm{MLCT}$ character involving the diimine ligand (see the computed spin densities of $T_{1}$ for all the complexes in Section D). The emission maximum wavelength for Ir $\mathbf{3}$ ' is blue-shifted compared to Ir1', due to the electron-withdrawing nature of the COOEt functions, that stabilizes the HOMO centered on the Ir-ppy. Conversely, the emission maximum wavelength for Ir4' is redshifted compared to Ir1' because the electron-donating nature of the triphenylamine moiety likely entails a destabilization of the HOMO. The structure of Ir2' is different from that of Ir1', Ir3' and Ir4' since it is the only complex in the series which bears no diimine ancillary ligand, and for this reason a direct comparison with the other complexes is less straightforward. DFT and TD-DFT calculations (vide infra) show that for Ir $\mathbf{2}, \mathrm{T}_{1}$ is of predominant ${ }^{3} \mathrm{MLCT}$ character, but in contrast to Ir1 and Ir3, it involves the cyclometalating ligand. Its emission wavelength maximum is slightly red-shifted with respect to $\left[\operatorname{Ir}(\mathrm{ppy})_{2}(\mathrm{acac})\right](516 \mathrm{~nm}[56,66]$ vs. $530 \mathrm{~nm}$ for $\left[\operatorname{Ir}(\mathrm{ppy})_{2}(\mathrm{acac})\right]$ and Ir2' respectively). The small bathochromic shift of the emission maximum wavelength likely originates from the presence of the $\mathrm{CH}_{2}-\mathrm{PO}_{3} \mathrm{Et}_{2}$ moieties. The emission lifetime of the complexes range between 60-460 ns in areared solution, which is much 
longer than typical hole injection rate constant in $\mathrm{NiO},[23]$ and they ranked in the following order : Ir 3' > Ir 4' $\approx$ Ir $\mathbf{2}^{\prime}$ > Ir $\mathbf{1}^{\prime}$ ' consistent with the energy gap law.

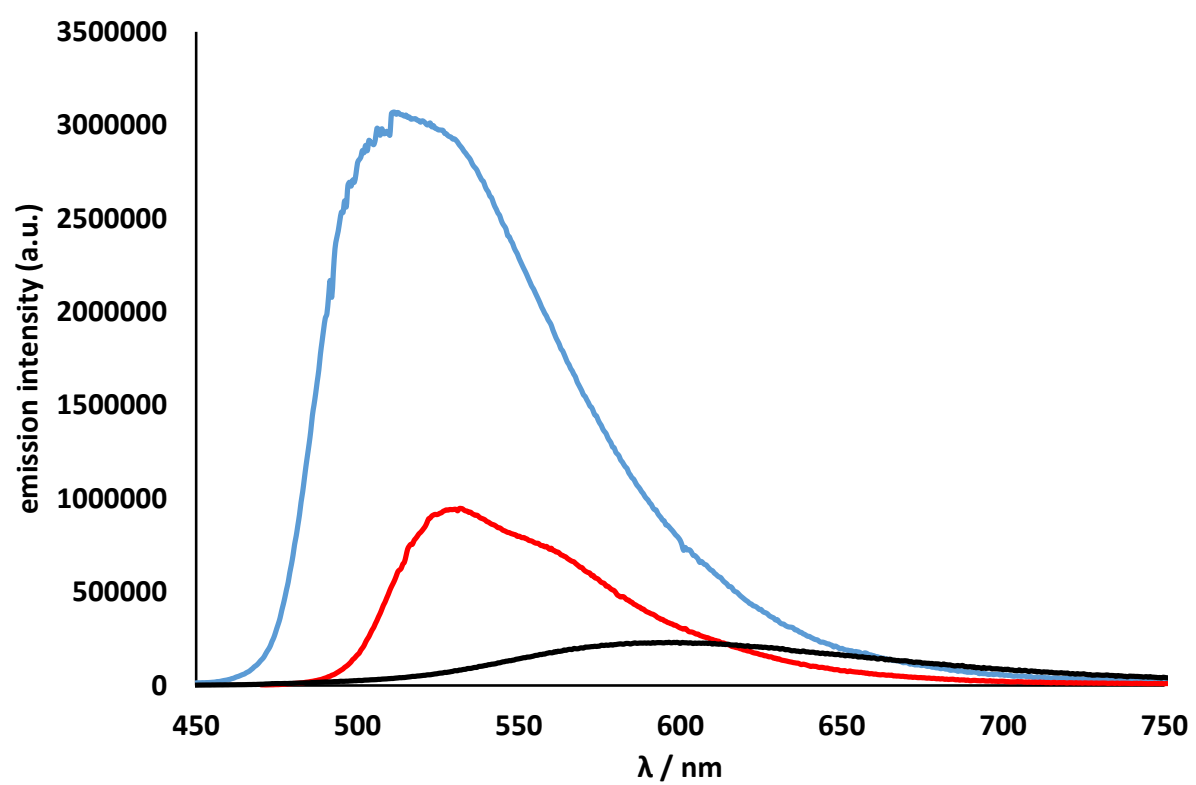

Figure 2. Emission spectra in dichloromethane for complexes Ir2' (excitation at $464 \mathrm{~nm}$, red line), Ir3' (excitation at $397 \mathrm{~nm}$, blue line) and Ir4' (excitation at $415 \mathrm{~nm}$, black line). Absorption at excitation wavelength are matched for Ir2' and Ir3', but not for Ir4' which was very insoluble in dichloromethane.

Table 1. Wavelengths of maximal absorption $\left(\lambda_{\text {abs }}\right)$ with extinction coefficient $(\varepsilon)$, wavelength of maximal emission $\left(\lambda_{\mathrm{em}}\right)$ and emission lifetime $\left(\tau_{\mathrm{em}}\right)$ recorded at room temperature in dichloromethane and zero-zero energy level of the lowest singlet excited state $\left(\mathrm{E}_{00}\right)$.

\begin{tabular}{|c|c|c|c|c|}
\hline Dyes & $\lambda_{\mathrm{abs}} / \mathrm{nm}\left(\varepsilon \times 10^{-3} / \mathrm{M}^{-1} \mathrm{~cm}^{-1}\right)$ & $\lambda_{\mathrm{em}} / \mathrm{nm}^{\mathrm{a}}$ & $\tau_{\mathrm{em}} / \mathrm{ns}^{\mathrm{b}}$ & $\begin{array}{c}{ }^{\mathrm{c}} \mathrm{E}_{00} / \\
\mathrm{eV}\end{array}$ \\
\hline Ir1' & $260(\mathrm{sh}) ; 380(\mathrm{sh}) ; 420(\mathrm{sh}) ; 470(1.1)$ & $579(625)$ & $(56)^{\mathrm{d}}$ & 2.34 \\
\hline Ir2' & $347(14.0) ; 372(9.1) ; 390(\mathrm{sh}) ; 414(5.8) ;$ & $530(554)$ & $\begin{array}{c}491 \\
(110)\end{array}$ & 2.41 \\
\hline Ir3' & $324(\mathrm{sh}) ; 349(13.0) ; 378(\mathrm{sh}) ; 400(6.2) ;$ & $531(517)$ & $\begin{array}{c}970 \\
(459)\end{array}$ & 2.61 \\
\hline Ir4' & $314(\mathrm{sh}) ; 348(58.0) ; 419(\mathrm{sh}) ; 484(\mathrm{sh})$ & $599(601)$ & $\begin{array}{c}483 \\
(170)\end{array}$ & 2.39 \\
\hline Ru4' & $295(82.0) ; 348(56.0) ; 405(\mathrm{sh}) ; 485$ & $-(844)$ & - & 1.69 \\
\hline
\end{tabular}

${ }^{\text {aCComputed }} \triangle$ SCF-PCM-B3LYP emission energy maxima for Ir1-4 and Ru4 are given in parenthesis. ${ }^{\mathrm{b}}$ measured by single photon counting in argon degassed solution and in parentheses 
lifetime measured in areared solution. ${ }^{c}$ measured at the bluest emission wavelength on the $77 \mathrm{~K}$ fluorescence spectra. ${ }^{\mathrm{d}}$ value measured in areared $\mathrm{CH}_{3} \mathrm{CN}$ and taken from reference 11 .

\section{Electrochemical study and electron transfer driving forces}

The three new sensitizers were studied by cyclic voltammetry to determine their redox potentials and to calculate the hole injection $\left(\Delta \mathrm{G}^{\circ}{ }_{\text {inj }}\right)$ and dye regeneration $\left(\Delta \mathrm{G}^{\circ}\right.$ reg $)$ driving forces (Table 2). The voltammograms of Ir1', Ir2', and Ir3' (Figure S5) display similar features with a pseudo-reversible iridium-ppy centered oxidation wave between ca. 1.3 and $1.55 \mathrm{~V}$ vs. SCE, and an irreversible ligand centered reduction wave between -1.4 and $-1.15 \mathrm{~V}$ vs. SCE. The calculations on the reduced radical species (see below) show that for Ir 1 and $\operatorname{Ir} 3$ the excess of electron density is mainly localized on the diimine ligand, whilst for Ir $\mathbf{2}$ this excess is located on both cyclometalating ligands. Comparing Ir1 and Ir3, there is a larger participation of the cyclometalating ligand for the latter (Figure 3). The reduction and oxidation potentials for Ir3' are anodically shifted compared to Ir1', likely due to the superior electron-withdrawing nature of COOEt compared to $\mathrm{CH}_{2}-\mathrm{PO}_{3} \mathrm{Et}_{2}$. The behavior of Ir2' is more difficult to rationalize. Indeed, one would expect cathodically shifted electrochemical processes compared to Ir1' by virtue of the strong electron donating character of the acac ligand.[56] However, the opposite behavior is observed. Ir 2' being neutral whereas Ir3' and Ir4' are cations, along with their different ligands involved in the electrochemical processes, could account for the observed differences.

The voltammogram of Ir4' differs from those of Ir2' and Ir3' in that three pseudo-reversible processes are observed at 1.00, 1.16 and $1.45 \mathrm{~V}$ vs. SCE, in addition to a reversible reduction wave at $-1.40 \mathrm{~V}$ vs. SCE. Based on the reversibility and the potential of the latter, this electrochemical process was assigned to a bpy-centered reduction. Indeed, the DFT calculations on its reduced radical species are consistent with such an assignment (see Figure 3), the excess of electron density being localized on both bpy units. Concerning the anodic part of the voltammogram, the electron-donating nature of the triphenylamine moiety conjugated to the ppy moiety destabilizes the frontier orbitals of the whole complex, leading to a shift of all oxidation potentials towards less positive values. One probably cannot associate the first oxidation process to the triphenylamine moiety alone, because the carbometallation implies a 
more intimate mixing of the metal and ligand orbitals compared to more classical coordination complexes with, e.g., bipyridine or phenanthroline.[68]

However, gathering both optical and electrochemical data allows to estimate thermodynamic parameters which are particularly relevant in the field of DSSC, namely the hole injection and dye regeneration driving forces with $\mathrm{I}_{3}{ }^{-} / \mathrm{I}^{-}$or $\mathbf{C o 1}^{3+} / \mathbf{C o 1}^{2+[53]}$ redox mediators (see Figure $\mathrm{S} 3$ in the SI for the structure of $\left.\mathbf{C o 1}^{3+}\right), \Delta \mathrm{G}^{\circ}$ inj, and $\Delta \mathrm{G}^{\circ}$ reg, respectively. The latter are given in Table 2 , and reveal that photo-induced hole injection and dye regeneration are very favorable processes for all iridium complexes. This is expected since cyclometalated iridium complexes like model Ir1' are strong photo-oxidants[16, 69, 70] with very negative reduction potentials, owing to the electron rich nature of the ppy ligand.

Table 2. Redox potentials recorded by cyclic voltammetry at room temperature in dichloromethane/DMF [95:5] solution with $\mathrm{Bu}_{4} \mathrm{NPF}_{6}(0.1 \mathrm{M})$ as supported electrolyte and referenced versus saturated calomel electrode (SCE). Calculated Gibbs free energies for hole injection $\left(\Delta \mathrm{G}^{\circ}{ }_{\text {inj }}\right)$ and dye regeneration $\left(\Delta \mathrm{G}^{\circ}{ }_{\mathrm{reg}}\right)$

\begin{tabular}{|c|c|c|c|c|c|c|}
\hline Dyes & $\begin{array}{c}\mathrm{E}\left(\mathrm{S}^{+} / \mathrm{S}\right)(\mathrm{V}) \\
\Delta \mathrm{E}(\mathrm{mV})\end{array}$ & $\begin{array}{c}\mathrm{E}_{1 / 2}\left(\mathrm{~S} / \mathrm{S}^{-}\right)(\mathrm{V}) \\
\Delta \mathrm{E}(\mathrm{mV})\end{array}$ & $\begin{array}{c}{ }^{a} \mathrm{E}\left(\mathrm{S}^{*} / \mathrm{S}^{-}\right) \\
(\mathrm{V})\end{array}$ & $\begin{array}{c}{ }^{\mathrm{b} \Delta \mathrm{G}^{\mathrm{o}} \mathrm{inj}} \\
(\mathrm{eV})\end{array}$ & $\begin{array}{c}{ }^{c} \Delta G^{\circ}{ }^{\circ} \text { g } \\
\text { with I }{ }^{-}{ }^{-} \\
(e V)\end{array}$ & 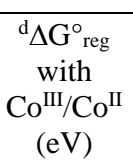 \\
\hline Ir1' & 1.29 & $-1.37^{\mathrm{e}}$ & 0.97 & -0.67 & -1.05 & -1.58 \\
\hline Ir2' & 1.35 & $-1.20^{\mathrm{e}}$ & 1.21 & -0.91 & -0.88 & -1.41 \\
\hline Ir3' & 1.54 & $-1.16^{\mathrm{e}}$ & 1.45 & -1.15 & -0.84 & -1.37 \\
\hline Ir4' & 1.00 & -1.40 & 0.99 & $\begin{array}{l}-0.69 \\
\end{array}$ & $\begin{array}{l}-1.08 \\
\end{array}$ & -1.61 \\
\hline
\end{tabular}

${ }^{\mathrm{a} C a l c u l a t e d}$ according to: $\mathrm{E}_{1 / 2}\left(\mathrm{~S}^{*} / \mathrm{S}^{-}\right)=\mathrm{E}_{1 / 2}\left(\mathrm{~S} / \mathrm{S}^{-}\right)+\mathrm{E}_{00} \cdot{ }^{\mathrm{b}}$ Calculated according to: $\Delta \mathrm{G}^{\circ}{ }_{\text {inj }}=$ $\mathrm{E}_{\mathrm{BV}}(\mathrm{NiO})-\mathrm{E}_{\mathrm{Red}}\left(\mathrm{S}^{*} / \mathrm{S}^{-}\right)$with $\mathrm{E}_{\mathrm{BV}}(\mathrm{NiO})=0.30 \mathrm{~V} v s$. SCE. ${ }^{\mathrm{c} C a l c u l a t e d}$ according to: $\Delta \mathrm{G}^{\circ}{ }_{\text {reg }}=$ $\mathrm{E}_{\text {Red }}\left(\mathrm{S} / \mathrm{S}^{-}\right)-\mathrm{E}\left(\mathrm{I}_{3}{ }^{-} / \mathrm{I}_{2}^{-\bullet}\right)$ with $\mathrm{E}\left(\mathrm{I}_{3}{ }^{-} / \mathrm{I}_{2}^{-\bullet}\right)=-0.32 \mathrm{~V} v s$. SCE. ${ }^{\mathrm{d} C a l c u l a t e d}$ according to: $\Delta \mathrm{G}^{\circ}{ }_{\text {reg }}=$ $\mathrm{E}_{\mathrm{Red}}\left(\mathrm{S} / \mathrm{S}^{-}\right)-\mathrm{E}\left(\mathbf{C o 1}^{3+} / \mathbf{C o 1}^{2+}\right)$ with $\mathrm{E}\left(\mathbf{C o 1}^{3+} / \mathbf{C o 1}^{2+}\right)=0.21 \mathrm{~V}$ vs. SCE. ${ }^{\mathrm{e}}$ Non reversible process, peak potential.

\section{Quantum chemical calculations}

To gain insights into the optical, electrochemical, and sensitizing properties for p-DSSCs of the dyes we have performed density functional theory (DFT) and Time-Dependent DFT (TD-DFT) calculations (see computational details in the experimental Section). Table 3 collects the TD- 
B3LYP vertical excitation energies, character, and oscillator strengths for the main lowest singlet and triplet excited states of Ir1-4 and Ru4, while the computed HOMO and LUMO energy levels are collected in Table S1. The computed data agree well with the measured UVVis spectra (compare to the values with Table 1). In addition, we optimized the geometries of i) the reduced radical species (see their spin density distributions in Figure 3); and ii) the lowest triplet excited states, i.e., $\mathrm{T}_{1}$ (see their corresponding spin density distributions in Figure 4). Both have been used in the analysis presented in the previous Section. To model the emission maxima, we computed the $\triangle$ SCF-PCM-B3LYP values at the latter geometries. These values are shown in Table 1. The emission-shifts in the series of complexes are well reproduced by the calculations.

Table 3. TD-B3LYP/6-31G(d) [ecp-mwb-60(28) for $\operatorname{Ir}(\mathrm{Ru})]$ main vertical singlet and triplet electronic transition energies (in $\mathrm{nm}$ and $\mathrm{eV}$ ), and oscillator strengths.

\begin{tabular}{|c|c|c|c|c|}
\hline Dyes & State & $\lambda$ [tategt] & $f$ [a.u.] & Character [Coeff.] \\
\hline \multirow{6}{*}{ Ir1 } & $\mathrm{S}_{1}$ & $470 / 2.636$ & 0.010 & $(\mathrm{H} \rightarrow \mathrm{L}) \mathrm{d}+\pi_{\mathrm{cycl}} \rightarrow \pi *_{\text {anc }}[0.70]$ \\
\hline & $\mathrm{S}_{2}$ & $443 / 2.795$ & 0.007 & $(\mathrm{H}-1 \rightarrow \mathrm{L}) \mathrm{d}+\pi_{\mathrm{cycl}} \rightarrow \pi *$ anc $[0.70]$ \\
\hline & $\mathrm{S}_{3}$ & $429 / 2.891$ & 0.008 & $(\mathrm{H} \rightarrow \mathrm{L}+1) \mathrm{d}+\pi_{\mathrm{cycl}} \rightarrow \pi *_{\mathrm{anc}}[0.70]$ \\
\hline & $\mathrm{S}_{5}$ & $381 / 3.251$ & 0.032 & $(\mathrm{H} \rightarrow \mathrm{L}+2) \mathrm{d}+\pi_{\mathrm{cycl}} \rightarrow \pi *_{\mathrm{cycl}}[0.67]$ \\
\hline & $\mathrm{S}_{6}$ & $373 / 3.32$ & 0.085 & $(\mathrm{H}-2 \rightarrow \mathrm{L}) \mathrm{d}+\pi_{\mathrm{cycl}} \rightarrow \pi *_{\text {anc }}[0.59]$ \\
\hline & $\mathrm{T}_{1}$ & $489 / 2.54$ & 0.000 & $(\mathrm{H} \rightarrow \mathrm{L}) \mathrm{d}+\pi_{\mathrm{cycl}} \rightarrow \pi *_{\text {anc }}[0.63]$ \\
\hline \multirow{6}{*}{ Ir2 } & $\mathrm{S}_{1}$ & $423 / 2.933$ & 0.010 & $(\mathrm{H} \rightarrow \mathrm{L}) \mathrm{d}+\pi_{\mathrm{cycl}} \rightarrow \pi *_{\text {cycl }}[0.69]$ \\
\hline & $\mathrm{S}_{2}$ & $402 / 3.081$ & 0.058 & $(\mathrm{H} \rightarrow \mathrm{L}+1) \mathrm{d}+\pi_{\mathrm{cycl}} \rightarrow \pi *_{\mathrm{cycl}}[0.67]$ \\
\hline & $\mathrm{S}_{4}$ & $385 / 3.217$ & 0.055 & $(\mathrm{H}-1 \rightarrow \mathrm{L}+1) \mathrm{d}+\pi_{\mathrm{cycl}}+\pi_{\mathrm{anc}} \rightarrow \pi *_{\mathrm{cycl}}[0.48]$ \\
\hline & $\mathrm{S}_{5}$ & $360 / 3.439$ & 0.014 & $(\mathrm{H}-2 \rightarrow \mathrm{L}) \mathrm{d}+\pi_{\mathrm{anc}} \rightarrow \pi *_{\mathrm{cycl}}[[0.60]$ \\
\hline & $\mathrm{T}_{1}$ & $476 / 2.604$ & 0.000 & $(\mathrm{H}-2 \rightarrow \mathrm{L}) \mathrm{d}+\pi_{\mathrm{anc}} \rightarrow \pi *_{\mathrm{cycl}}[0.61]$ \\
\hline & $\mathrm{T}_{2}$ & $454 / 2.731$ & 0.000 & $(\mathrm{H}-1 \rightarrow \mathrm{L}+1) \mathrm{d}+\pi_{\mathrm{cycl}}+\pi_{\mathrm{anc}} \rightarrow \pi *_{\mathrm{cycl}}[0.43]$ \\
\hline \multirow{6}{*}{ Ir3 } & $\mathrm{S}_{1}$ & $425 / 2.921$ & 0.015 & $(\mathrm{H} \rightarrow \mathrm{L}) \pi_{\mathrm{cycl}} \rightarrow \pi *_{\mathrm{cycl}}[0.69]$ \\
\hline & $\mathrm{S}_{2}$ & $418 / 2.967$ & 0.007 & $(\mathrm{H} \rightarrow \mathrm{L}+1) \pi_{\mathrm{cycl}} \rightarrow \pi *_{\text {anc }}[0.68]$ \\
\hline & $\mathrm{S}_{4}$ & $398 / 3.115$ & 0.021 & $(\mathrm{H}-1 \rightarrow \mathrm{L}) \pi_{\mathrm{anc}} \rightarrow \pi *_{\mathrm{cycl}}[0.66]$ \\
\hline & $\mathrm{S}_{7}$ & $377 / 3.290$ & 0.056 & $(\mathrm{H}-1 \rightarrow \mathrm{L}+2) \pi_{\mathrm{anc}} \rightarrow \pi *_{\mathrm{cycl}}[0.58]$ \\
\hline & $\mathrm{T}_{1}$ & $475 / 2.608$ & 0.000 & $(\mathrm{H} \rightarrow \mathrm{L}+1) \pi_{\mathrm{cycl}} \rightarrow \pi *_{\mathrm{anc}}[0.48]$ \\
\hline & $\mathrm{T}_{2}$ & $458 / 2.710$ & 0.000 & $(\mathrm{H}-1 \rightarrow \mathrm{L}+2) \pi_{\mathrm{anc}} \rightarrow \pi *_{\mathrm{cycl}}[0.41]$ \\
\hline
\end{tabular}




\begin{tabular}{|c|c|c|c|c|}
\hline & $\mathrm{S}_{1}$ & $503 / 2.463$ & 0.001 & $(\mathrm{H} \rightarrow \mathrm{L}) \pi_{\mathrm{tpa}} \rightarrow \pi *_{\text {bpy }}[0.69]$ \\
& $\mathrm{S}_{2}$ & $474 / 2.161$ & 0.014 & $(\mathrm{H}-1 \rightarrow \mathrm{L}) \mathrm{d}+\pi_{\mathrm{ppy}} \rightarrow \pi *_{\text {bpy }}[0.69]$ \\
& $\mathrm{S}_{3}$ & $436 / 2.841$ & 0.004 & $(\mathrm{H}-2 \rightarrow \mathrm{L}) \mathrm{d}+\pi_{\mathrm{ppy}} \rightarrow \pi *_{\text {bpy }}[0.67]$ \\
& $\mathrm{S}_{6}$ & $383 / 3.238$ & 0.423 & $(\mathrm{H} \rightarrow \mathrm{L}+4) \pi_{\mathrm{tpa}} \rightarrow \pi *_{\mathrm{tpa}}[0.70]$ \\
& $\mathrm{T}_{1}$ & $506 / 2.451$ & 0.000 & $(\mathrm{H} \rightarrow \mathrm{L}) \pi_{\mathrm{tpa}} \rightarrow \pi *_{\mathrm{bpy}}[0.59]$ \\
& $\mathrm{T}_{2}$ & $500 / 2.482$ & 0.000 & $(\mathrm{H}-1 \rightarrow \mathrm{L}) \mathrm{d}+\pi_{\mathrm{ppy}} \rightarrow \pi *_{\mathrm{bpy}}[0.49]$ \\
\hline \multirow{5}{*}{$\mathbf{R u 4}$} & $\mathrm{S}_{1}$ & $616 / 2.013$ & 0.002 & $(\mathrm{H} \rightarrow \mathrm{L}) \mathrm{d}+\pi_{\mathrm{ppy}} \rightarrow \pi *_{\mathrm{bpy}}[0.63]$ \\
& $\mathrm{S}_{2}$ & $614 / 2.021$ & 0.003 & $(\mathrm{H}-1 \rightarrow \mathrm{L}) \mathrm{d}+\pi_{\mathrm{tpa}} \rightarrow \pi *_{\mathrm{bpy}}[0.60]$ \\
& $\mathrm{S}_{3}$ & $550 / 2.255$ & 0.019 & $(\mathrm{H}-2 \rightarrow \mathrm{L}) \mathrm{d}+\pi_{\mathrm{tpa}} \rightarrow \pi *_{\mathrm{bpy}}[0.50]$ \\
& $\mathrm{S}_{5}$ & $507 / 2.445$ & 0.114 & $(\mathrm{H}-2 \rightarrow \mathrm{L}+1) \mathrm{d}+\pi_{\mathrm{tpa}} \rightarrow \pi *_{\mathrm{bpy}}[0.44]$ \\
& $\mathrm{T}_{1}$ & $676 / 1.835$ & 0.000 & $(\mathrm{H} \rightarrow \mathrm{L}+1) \mathrm{d}+\pi_{\mathrm{ppy}} \rightarrow \pi *_{\mathrm{bpy}}[0.61]$ \\
& $\mathrm{T}_{2}$ & $649 / 1.910$ & 0.000 & $(\mathrm{H} \rightarrow \mathrm{L}) \mathrm{d}+\pi_{\mathrm{ppy}} \rightarrow \pi *_{\mathrm{bpy}}[0.39]$ \\
\hline
\end{tabular}
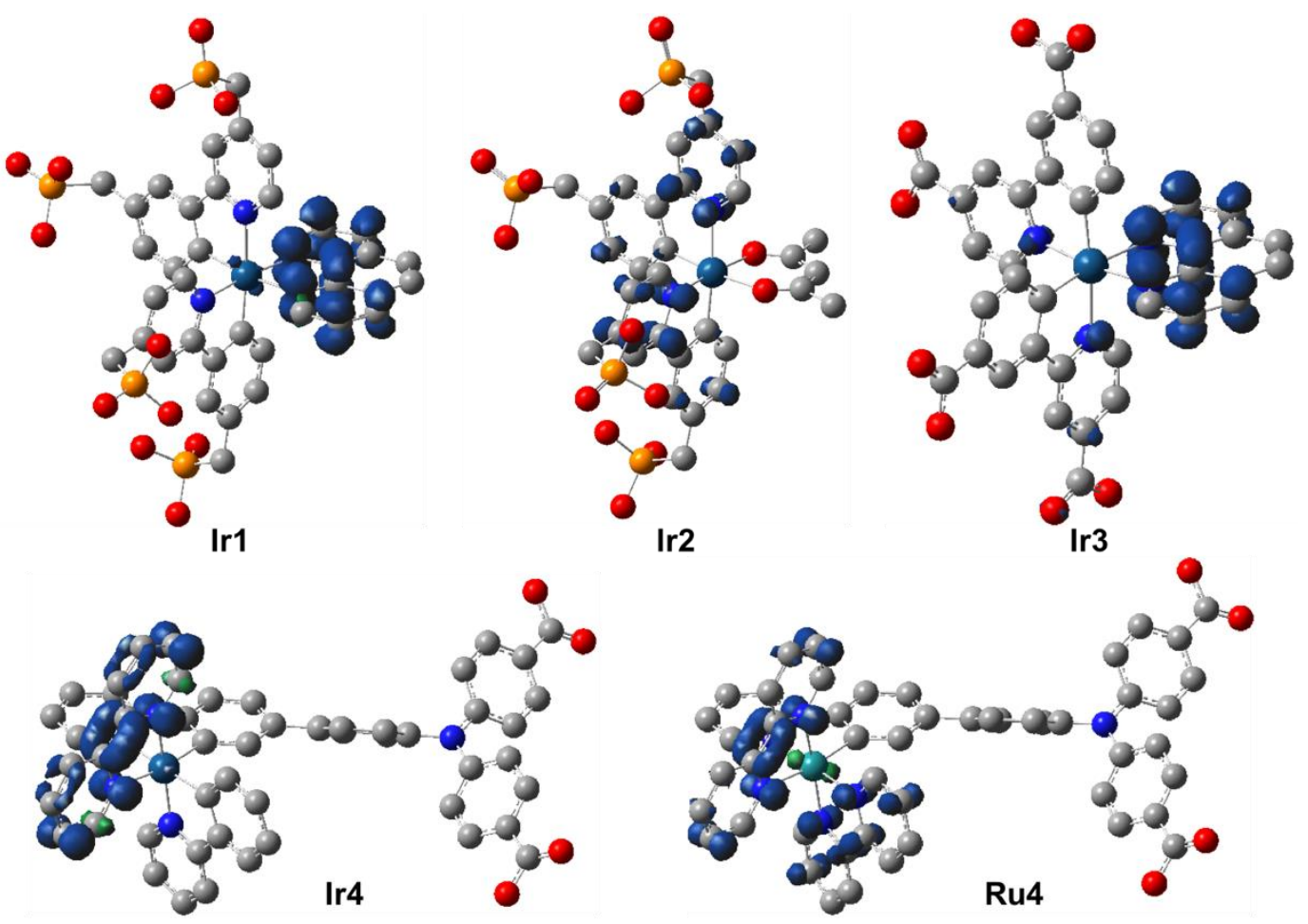

Figure 3. Spin density plots (UB3LYP/6-31G(d)) of the reduced radical species of the dyes. Hydrogen atoms are omitted for clarity. 


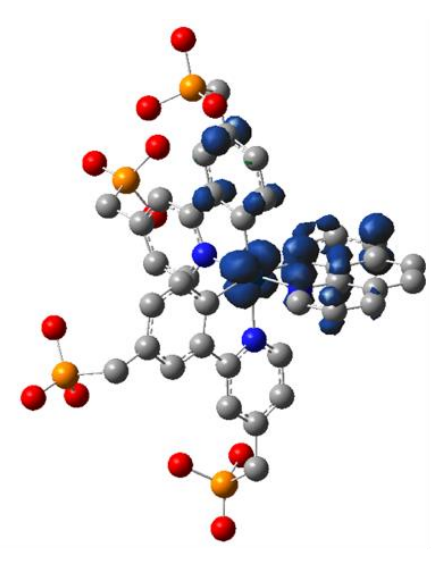

Ir1

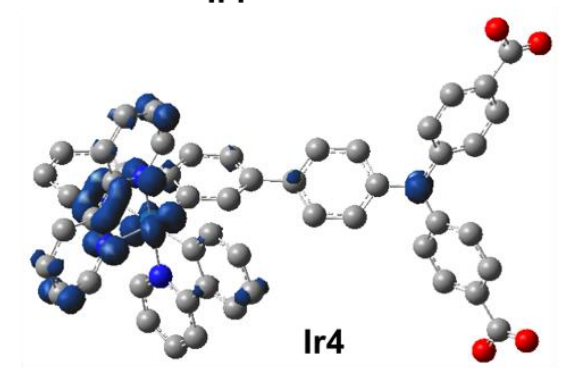

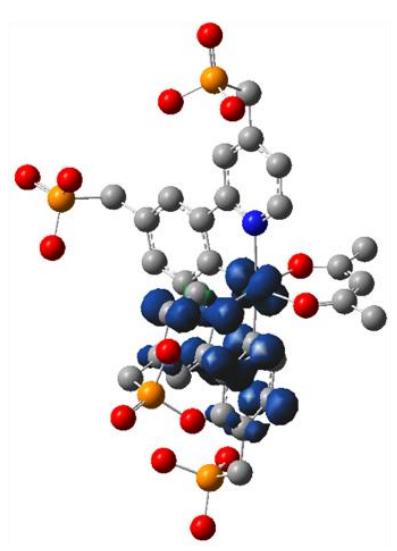

Ir2

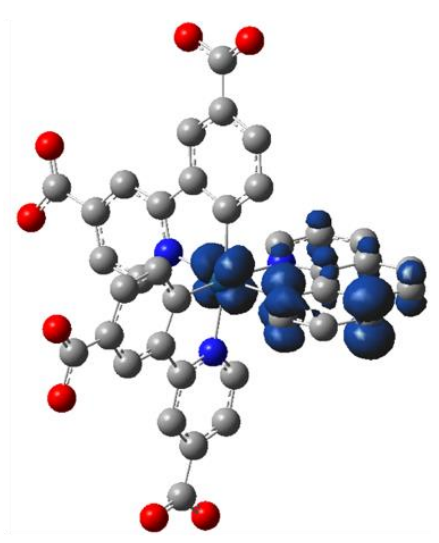

Ir3

Figure 4. Spin density plots (UB3LYP/6-31G(d)) of the lowest triplet excited states of the dyes. Hydrogen atoms are omitted for clarity.

\section{Photovoltaic measurements}

p-DSSC where a $2 \mu \mathrm{m}$-thick layer of mesoporous $\mathrm{NiO}$ was dyed with each iridium complexes were prepared with iodine or cobalt complex based electrolytes (see Experimental Section for details). $\mathrm{I}_{3}{ }^{-} / \mathrm{I}^{-}$electrolytes are commonly used for $\mathrm{p}$-DSSC while they are not necessarily adequate because of their strong coloration, their quite high oxidation potential and favored reactions with holes in the valence band of $\mathrm{NiO}$, all contributing to low Voc. Thus, Co1 (Figure S6) was designed to generate high Voc because its steric bulk limits deleterious interactions between the latter and holes in the valence band of $\mathrm{NiO}$; but this steric bulk also entails a slow diffusion coefficient and slow kinetics for dye regeneration. As a consequence, this electrolyte is only compatible with photo-electrodes where the interfacial CSS is long lived.[33]

The devices were subsequently tested under simulated AM1.5 solar light. The corresponding figures of merit are given in Table 4. p-DSSCs with previously published Ir1 dye were assembled for the sake of comparison.[23] First of all, complexes Ir2 and Ir3 performed poorly as photosensitizers for p-DSSC. As a matter of fact, the photocurrent and the experimental errors are similar for those two complexes indicating that they essentially do not work. The 
poor light harvesting efficiency of these complexes cannot solely account for this result as Ir1, Ir2 and Ir3 possess similar UV-Vis absorption properties. Regardless of the selected electrolyte, both Jsc and Voc are substantially smaller for Ir2 and Ir3 based p-DSSC compared to Ir1's, likely meaning that the photo-induced processes are dominated by charge recombination in Ir2 and Ir3. In the case of Ir2, this is likely due to the reduced radical species fully localized on the anchoring ligand, which favors geminate charge recombination. In this regard, we underline the importance of a methylene spacer between the phosphonic acid and the ppy ligand in Ir1 that allows to electronically disconnect the electron-withdrawing anchoring groups from the iridium complex. This is reflected by the spin density plots of the reduced radical species of Ir1 and Ir3: the certain participation of the anchoring ligand is present in the latter only. Overall, those results put premium on the impact of the electronic decoupling of the CSS and the ground state, which is a mandatory matter to take into account for the dye design.

On the other hand, p-DSSC elaborated with Ir4 as photosensitizer exhibit a higher Jsc and a significantly large Voc. The higher photocurrent is partly due to the better light harvesting efficiency of Ir4 (see Table 4) but the additional intense band observed in the latter complex is mostly developed in the UV part of the solar spectrum (below $400 \mathrm{~nm}$ ) where there are only few solar photons to harvest. This band is due to a transition from the ground state to ${ }^{1} \mathrm{LC}$ state (ligand centered) at the triphenylamine (tpa) ligand (see state $\mathrm{S}_{6}$ in Table 3).On the other hand, the p-DSSC sensitized with Ir1 exhibits a higher Voc and ff than with Ir4 These discrepancies can most probably be explained by a different shielding of the NiO surface by the sensitizer. It was demonstrated that interfacial charge recombination (between the holes into $\mathrm{NiO}$ and the redox mediator) is much more severe than in classical $\mathrm{TiO}_{2}$ based DSSC.[33, 55, 56] Accordingly, the surface passivation of the NiO surface by the dye, which depends on the packing of the dye and therefore on its structure, strongly impacts this factor. Iodide anion being a smaller compound than the cobalt complex with diterbutylpyridine ligands, the interfacial charge recombination are more important with the former, leading thus to a higher Voc and ff. Ru4-based p-DSSC with iodide/triiodide electrolyte exhibits a much higher Jsc in agreement with the report of $\mathrm{Wu}$ and co-workers.[48] This is certainly the consequence of the larger LHE of the Ru complex thanks to its MLCT bands much more extended in the visible region, as also outlined by our TD-B3LYP calculations (compare the results for Ir4 and Ru4 in Table 3). Moreover, both calculations and electrochemical data indicate that the HOMO of the Ir4 and Ru4 complexes is delocalized over the tpa-ppy-Ru units, whereas the LUMO is on the bpy: this 
electronic configuration is ideal for a dye designed for p-DSSC since hole injection from the dye to $\mathrm{NiO}$ through the HOMO is favored and the extra electron after hole injection is shifted away from the semi-conductor's surface (see also Figure 3). Both features tend to favor a longlived interfacial CSS, leading to a better charge collection efficiency and thus a higher photoconversion efficiency. In contrast, with the cobalt electrolyte, Ir4 complex exhibits a slightly larger Jsc but most importantly a much higher Voc than Ru4 in spite of the larger LHE of the latter. Interestingly, Ru4 and Ir4 share those electronic structures, so that they both will lead in an efficient manner to the lowest $\mathrm{T}_{1}$ state upon deactivation, yet the CSS is very short lived in the case of Ru4 as exemplified by the photophysical study of $\mathrm{Wu}$ and co-workers[48] and the poor Voc of Ru4-based p-DSSC compared to Ir4's with the $\mathbf{C o 1}^{3+} / \mathbf{C o 1}^{2+}$ electrolyte (Table 4). If Ir4 had a similarly short-lived CSS it could not lead to higher Jsc and Voc with this cobalt electrolyte. The most likely rationale for this experimental fact is that, like in several published iridium based molecular dyads and triads, [30, 31, 43] the formation of $\mathrm{NiO}(+) \mid \mathrm{Dye}(-$ ) interfacial CSS triplet in nature, conferring to the excited state an unusually long lifetime.

Table 4. Photoelectrochemical Metrics of the p-DSSCs sensitized with Ir1, Ir2, Ir3, Ir4 and Ru4 complexes, employing either the triiodide/iodide $\left(\mathrm{I}_{3}^{-} / \mathrm{I}^{-}\right)$or cobalt $\left(\mathbf{C o 1}^{3+} / \mathbf{C o 1}^{2+}\right)$ electrolytes recorded under AM1.5 G Simulated Sunlight $\left(1000 \mathrm{~W} / \mathrm{m}^{2}\right)$.

\begin{tabular}{|c|c|c|c|c|c|}
\hline Dye & Electrolyte & Jsc $\left(\mathrm{mA} / \mathrm{cm}^{2}\right)$ & Voc $(\mathrm{mV})$ & FF (\%) & $\eta(\%)$ \\
\hline \multirow[t]{2}{*}{ Ir1 } & $\mathrm{I}_{3}{ }^{-} / \mathrm{I}^{-}$ & $0.18 \pm 0.01$ & $166.8 \pm 1.8$ & $38.0 \pm 0.7$ & $0.011 \pm 0.001$ \\
\hline & $\mathrm{Co1}^{3+} / \mathrm{Co1}^{2+}$ & $0.14 \pm 0.01$ & $339.9 \pm 4.9$ & $44.9 \pm 0.4$ & $0.021 \pm 0.001$ \\
\hline \multirow[t]{2}{*}{ Ir2 } & $\mathrm{I}_{3}{ }^{-} / \mathrm{I}^{-}$ & $<0.05$ & - & - & - \\
\hline & $\mathrm{Co1}^{3+} / \mathrm{Co1}^{2+}$ & $<0.07$ & - & - & - \\
\hline \multirow[t]{2}{*}{ Ir3 } & $\mathrm{I}_{3}{ }^{-} / \mathrm{I}^{-}$ & $0.13 \pm 0.03$ & $91.1 \pm 11.1$ & $31.9 \pm 0.9$ & $0.0037 \pm 0.0004$ \\
\hline & $\mathrm{Co1}^{3+} / \mathrm{Co1}^{2+}$ & $<0.07$ & - & - & - \\
\hline \multirow[t]{2}{*}{ Ir4 } & $\mathrm{I}_{3}{ }^{-} / \mathrm{I}^{-}$ & $0.12 \pm 0.01$ & $81.8 \pm 4.4$ & $34.8 \pm 1.7$ & $0.0034 \pm 0.0005$ \\
\hline & $\mathrm{Co1}^{3+} / \mathrm{Co1}^{2+}$ & $0.32 \pm 0.03$ & $315.8 \pm 0.9$ & $34.9 \pm 0.2$ & $0.035 \pm 0.002$ \\
\hline \multirow[t]{2}{*}{ Ru4 } & $\mathrm{I}_{3}{ }^{-} / \mathrm{I}^{-}$ & $0.96 \pm 0.06$ & $103.2 \pm 2.1$ & $37.3 \pm 1.0$ & $0.037 \pm 0,002$ \\
\hline & $\mathrm{Co1}^{3+} / \mathrm{Co1}^{2+}$ & $0.17 \pm 0.03$ & $79.2 \pm 0.9$ & $33.0 \pm 1.5$ & $0.0043 \pm 0.0008$ \\
\hline
\end{tabular}

In terms of photovoltaic performances in p-DSSCs, if these new Ir complexes are compared to other published results, $[20,23,25,54]$ they produced lower photocurrent density owing to their lower LHE. However, Ir1 and Ir4 present the real advantages to be compatible with cobalt electrolyte, which requires low charge recombination. 


\section{E. Conclusion}

In this study, three new iridium complexes were prepared and investigated in p-DSSC with two different electrolytes (triiodide/iodide and tris(4,4'-ditert-butyl-2,2'-bipyridine)cobalt(III/II)) to deepen our understanding of the larger Voc and long-lived charge separated state measured on NiO based p-DSSC with a cobalt electrolyte with a series of complexes based on Ir1. The main findings of this work are, first, that electronic decoupling of the charge separated state with the ground state is certainly highly beneficial when dealing with dye having significantly long lived excited state (mostly dyes with triplet excited states). The electronic decoupling can be obtained by using anchoring groups not conjugated to the dye and/or by forcing the localization of the LUMO on a ligand ancillary ligand which is located at a long distance from the $\mathrm{NiO}$ surface. The other important conclusion of this investigation is that iridium complexes exhibit distinct behavior compared to the corresponding ruthenium analogs in p-DSSC, and to all other dyes specially developed for p-DSSC, as demonstrated by the large differences in photovoltaic performances with the cobalt electrolyte. We propose that these peculiar properties come from the formation of a triplet charge separated state $\left({ }^{3}\left(-\mathrm{Ir} / \mathrm{NiO}^{+}\right)\right)$induced by the high spin-orbit coupling promoted by iridium.

These results provide further insights into the mechanisms controlling the kinetics of interfacial electron-transfer processes in p-DSSCs. In addition, to our knowledge, it is the first time that triplet charge separated state is invoked in DSSC and enables to attain long lived charge separated state. Although iridium dyes presented in this contribution are weak absorbers (and consequently feature poor light harvesting efficiencies compared to other dyes), they pave the way to a new way of engineering dyes with long lived interfacial charge separated states. These information are of great relevance to the future design of dye-sensitized solar cells and dyesensitized photoelectrosynthesis cells.

\section{F. Experimental part}

\section{General}

Thin-layer chromatography (TLC) was performed on aluminium sheets precoated with Merck 5735 Kieselgel $60 \mathrm{~F}_{254}$. Column chromatography was carried out either with Merck 5735 Kieselgel 60F (0.040-0.063 mm mesh). Chemicals were purchased from Sigma-Aldrich or Alfa Aesar and used as received. ${ }^{1} \mathrm{H}$ and ${ }^{13} \mathrm{C}$ spectra were recorded on a Bruker $A R X 300 \mathrm{MHz}$, AVANCE 300 ultrashield BRUKER, AVANCE 400 BRUKER or AVANCE III 500 BRUKER. 
Chemical shifts for ${ }^{1} \mathrm{H}$ NMR spectra are referenced relative to residual protium in the deurated solvent $\left(\mathbf{C D C l}_{\mathbf{3}} \delta=7.26 \mathrm{ppm}\right.$ for ${ }^{1} \mathrm{H}$ and $\delta=77.16 \mathrm{ppm}$ for ${ }^{13} \mathrm{C} ; \mathbf{C D}_{\mathbf{3}} \mathbf{O D} \delta=3.31 \mathrm{ppm}$ for ${ }^{1} \mathrm{H}$ and $\delta=49.00 \mathrm{ppm}$ for ${ }^{13} \mathrm{C}, \mathbf{D}_{\mathbf{2}} \mathbf{O} \delta=4.79 \mathrm{ppm}$ for ${ }^{1} \mathrm{H}$ ) or to an internal reference (TMS, $\delta=0 \mathrm{ppm}$ for both ${ }^{1} \mathrm{H}$ and ${ }^{13} \mathrm{C}$ ). Spectra were recorded at room temperature, chemical shifts are written in ppm and coupling constants in Hz. All NMR spectra are available in supporting information, Figures S7 to S14. High-resolution mass spectra (HR-MS) were obtained either by electrospray ionization coupled with high resolution ion trap orbitrap (LTQ-Orbitrap, ThermoFisher Scientific,) or by MALDI-TOF-TOF (Autoflex III de Bruker), both working in ion-positive mode and with 2,5-dihydroxybenzoic acid (DHB) or dithranol as matrix. Electrochemical measurements were performed with a potentiostat-galvanostat AutoLab PGSTAT 302N controlled by Nova software, using a conventional single-compartment three-electrode cell. The working electrode was a glassy carbon or a platinum electrode. The auxiliary was a Pt plate of $1 \mathrm{~cm}^{2}$ and the reference electrode was the saturated potassium chloride calomel electrode (SCE). The supporting electrolyte was $0.1 \mathrm{~N} \mathrm{Bu}_{4} \mathrm{NPF}_{6}$ in $\mathrm{CH}_{3} \mathrm{CN}$ or $\mathrm{CH}_{2} \mathrm{Cl}_{2}$ and solutions were purged with argon before the measurements. All potentials are quoted relative to SCE. In all the experiments the scan rate was $100 \mathrm{mV} / \mathrm{s}$. UV-Visible absorption spectra were recorded on a $U V$-2401PC Shimadzu spectrophotometer using $1 \mathrm{~cm}$ path length cells. Emission spectra were recorded on a Fluoromax-4 Horiba Jobin Yvon spectrofluorimeter (1 cm quartz cells).

\section{Photovoltaic cell fabrication}

Conductive glass substrates (F-doped $\mathrm{SnO}_{2}$ ) were purchased from Pilkington (TEC8, sheet resistance $8 \Omega$ /square). Conductive glass substrates were successively cleaned by sonication in soapy water, then ethanol for $10 \mathrm{~min}$ before being fired at $450{ }^{\circ} \mathrm{C}$ for $30 \mathrm{~min}$. Once cooled down to room temperature, FTO plates were rinsed with ethanol and dried in ambient air. $\mathrm{NiO}$ electrodes were prepared by screen-printing of a NiO paste on clean FTO substrates, using a commercial semiautomatic screen printer. The NiO screen-printing paste was produced by preparing a slurry of $3 \mathrm{~g}$ of $\mathrm{NiO}$ nanopowder (Inframat) suspended in $10 \mathrm{~mL}$ of distilled ethanol and ball-milled (500 rpm) for $24 \mathrm{~h}$. The resulting slurry was mixed in a round-bottom flask with $10 \mathrm{ml}$ of $10 \mathrm{wt} \%$ ethanolic ethyl cellulose (Sigma Aldrich) solution and $20 \mathrm{ml}$ terpineol, followed by slow ethanol removal by rotary evaporation. The dried film was then annealed at in air at $400{ }^{\circ} \mathrm{C}$ for $0.5 \mathrm{~h}$. The prepared $\mathrm{NiO}$ electrodes were soaked while still hot $\left(80^{\circ} \mathrm{C}\right)$ in a $0.1 \mathrm{mM}$ solution of each dye overnight in methanol. The electrolyte composition is $0.03 \mathrm{M} \mathrm{I}_{2}$, $0.1 \mathrm{M}$ guanidinium thiocyanate, $0.6 \mathrm{M}$ 1,2-dimethyl-3-butylimidazolium iodide and $0.5 \mathrm{M} 4$ - 
tert-butylpyridine in acetonitrile for the iodine based electrolyte, and $0.1 \mathrm{M} \mathrm{Co}^{\mathrm{II}}(\mathrm{dtb}-\mathrm{bpy})_{3}, 0.1$ $\mathrm{M} \mathrm{Co}^{\mathrm{III}}(\mathrm{dtb}-\mathrm{bpy})_{3}$ and $0.1 \mathrm{M} \mathrm{LiClO}_{4}$ in propylene carbonate for the cobalt based electrolyte. Counter electrodes were prepared by chemical deposition of platinum from hexachloroplatinic acid in distilled isopropanol ( $2 \mathrm{mg}$ per $\mathrm{mL}$ ). The two electrodes were placed on top of each other using a thin transparent film of Surlyn polymer (DuPont, $25 \mu \mathrm{m}$ ) as a spacer to form the electrolyte space. The empty cell was tightly held, and the edges were heated to $110^{\circ} \mathrm{C}$ to seal the two electrodes together. A drop of electrolyte was introduced through a predrilled hole in the counter electrode by vacuum backfilling, and was sealed afterward. The cell had an active area of $c a .0 .25 \mathrm{~cm}^{2}$.

The current-voltage characteristics were determined by applying an external potential bias to the cell and measuring the photocurrent using a Keithley model 2400 digital source meter. The solar simulator is an Oriel Lamp calibrated to $100 \mathrm{~mW} / \mathrm{cm}^{2}$. The overall conversion efficiency (PCE) of the photovoltaic cell is calculated by multiplying the short circuit photocurrent density $\left(\mathrm{J}_{\mathrm{sc}}\right)$, the open-circuit photovoltage $\left(\mathrm{V}_{\mathrm{oc}}\right)$, the fill factor of the cell $(\mathrm{FF})$, and dividing by the intensity of the incident light (AM1.5, $100 \mathrm{~mW} \cdot \mathrm{cm}^{-2}$ ).

\section{Compound Ir2'}

Complex $1(0.070 \mathrm{~g}, 0.031 \mathrm{mmol})$, acetylacetone $(0.050 \mathrm{~g}, 0.50 \mathrm{mmol})$, potassium carbonate $(0.043 \mathrm{~g}, 0.31 \mathrm{mmol})$ were dissolved in $10 \mathrm{ml}$ of 2-ethoxyethanol. The resulting mixture was freed from oxygen by argon bubbling while sonicating (20 min) and the solution was refluxed under argon overnight. After cooling to room temperature, the crude product was purified by flash column chromatography (silica gel, $\mathrm{CH}_{2} \mathrm{Cl}_{2}$ /petroleum ether gradient, from $1 / 1$ to pure $\mathrm{CH}_{2} \mathrm{Cl}_{2}$ and finally $\mathrm{CH}_{2} \mathrm{Cl}_{2} / \mathrm{MeOH}$ gradient, from 97/3 to 9/1) to afford the orange desired complexe Ir2' (0.035 g, 55\%).

${ }^{1}$ HNMR (400 MHz, CDCl $): \delta_{\mathrm{H}} 8.38(\mathrm{~d}, \mathrm{~J}=5.94 \mathrm{~Hz}, 2 \mathrm{H}), 7.74(\mathrm{~m}, 2 \mathrm{H}), 7.46(\mathrm{~m}, 2 \mathrm{H}), 7.13$ $(\mathrm{dt}, \mathrm{J}=1.94,5.94 \mathrm{~Hz}, 2 \mathrm{H}), 6.55(\mathrm{dt}, \mathrm{J}=2.06,7.88 \mathrm{~Hz}, 2 \mathrm{H}), 6.12(\mathrm{~d}, \mathrm{~J}=7.77 \mathrm{~Hz}, 2 \mathrm{H}), 5.18$ (s, 1H), $4.11(\mathrm{~m}, 8 \mathrm{H}), 3.88(\mathrm{~m}, 8 \mathrm{H}), 3.31(\mathrm{~d}, \mathrm{~J}=21.47 \mathrm{~Hz}, 4 \mathrm{H}), 2.97$ (d, J = 21.01 Hz, 4H), 1.30 $(\mathrm{dt}, \mathrm{J}=6.85,13.25 \mathrm{~Hz}, 12 \mathrm{H}), 1.10(\mathrm{t}, \mathrm{J}=7.31 \mathrm{~Hz}, 12 \mathrm{H})$.

${ }^{13}$ CNMR (101 MHz, CDCl 3 ): $\delta_{\mathrm{c}}$ 184.53, 168.53, 148.03, 145.93, 144.85, 142.39, 142.30, $133.23,130.56,130.50,125.27,125.20,122.99$, 122.90, 122.85, 122.75, 119.74, 119.67, 
$100.43,62.66,62.59,62.54,62.01,61.97,34.50,34.03,33.14,32.65,28.67,16.44,16.36$, $16.32,16.26$.

${ }^{31}$ P NMR (162 MHz, CDCl 3 ): $\delta_{\mathrm{p}} 27.99$ (s), 24.45 (s).

MALDI-TOF: m/z: Calculated for: $1221.3041[\mathrm{M}-\mathrm{Na}]+, 1221.3012[\mathrm{M}-\mathrm{Na}]+, \Delta=2.4 \mathrm{ppm}$.

\section{Compound Ir2}

$\mathrm{Me}_{3} \operatorname{SiBr}(323 \mu 1,2.45 \mathrm{mmol})$ was added to a solution of Ir2' $(0.029 \mathrm{~g}, 0.025 \mathrm{mmol})$ in distilled $\mathrm{CH}_{2} \mathrm{Cl}_{2}(5 \mathrm{~mL})$, and the resulting orange solution was stirred under reflux and argon for $4 \mathrm{~h}$. During this time, a slight color changes was observed. The solvent and the excess of $\mathrm{Me}_{3} \mathrm{SiBr}$ were removed under high vacuum. The solid residue was redissolved in $\mathrm{CH}_{3} \mathrm{OH}(20 \mathrm{~mL})$ and stirred overnight at room temperature. The red solid was filtered, washed with $\mathrm{MeOH}$, pentane and $\mathrm{Et}_{2} \mathrm{O}$ and finally dried under vacuum. The $\mathrm{pH}$ was adjusted with $\mathrm{AcOH}$ around 6 to obtain the desired red solid (Ir2, $0.013 \mathrm{~g}, 42 \%)$.

${ }^{1}$ H NMR (400 MHz, D $\mathbf{2}$, pD $\approx$ 8.5): $\delta_{\mathrm{H}} 8.83$ (s br, 2H), 7.96 (s, 2H), 7.63 (s, 2H), 7.37 (s br, 2H), $6.65(\mathrm{~d}, \mathrm{~J}=7.29 \mathrm{~Hz}, 2 \mathrm{H}), 6.23(\mathrm{~d}, \mathrm{~J}=7.65 \mathrm{~Hz}, 2 \mathrm{H}), 3.36(\mathrm{~s} \mathrm{br}, 6 \mathrm{H}), 3.15$ (d, J = $19.99 \mathrm{~Hz}$, $4 \mathrm{H}), 2.69(\mathrm{~d}, \mathrm{~J}=19.18 \mathrm{~Hz}, 4 \mathrm{H})$. One proton of acac around $5 \mathrm{ppm}$ is missing, probably due to deuterium exchange in $\mathrm{D}_{2} \mathrm{O}$ ).

${ }^{13}$ C NMR (101 MHz, $\mathbf{D}_{2}$ O, pD $\approx$ 8.5): 197.60, 168.44, 166.66, 149.92, 148.10, 147.95, 145.84, $132.34,130.42,125.13,123.58,49.90,48.87,38.30,37.20,35.98$.

${ }^{31}$ P NMR (162 MHz, $\left.\mathbf{D}_{2} \mathrm{O}, \mathbf{p D} \approx \mathbf{8 . 5}\right): \delta_{\mathrm{p}} 18.64(\mathrm{~s}), 16.09(\mathrm{~s})$.

\section{Compound Ir3'}

To a gun dried round bottomed flask under argon atmosphere containing 2 ( $0.070 \mathrm{~g}, 0.044$ mmol) and phenanthroline $(0.019 \mathrm{~g}, 0.097 \mathrm{mmol})$ were added degassed $\mathrm{MeOH}(3 \mathrm{~mL})$ and degassed $\mathrm{CH}_{2} \mathrm{Cl}_{2}(7 \mathrm{~mL})$. The mixture was heated to reflux under vigorous stirring for 3 hours. Then the yellow solution was allowed to cool to room temperature and the solvent was evaporated. The product was then solubilized in $\mathrm{MeOH}$, filtrated on millipore and the filtrate was collected and evaporated. The product was then purified a second time by filtration with EtOH. The dried product was dissolved in $\mathrm{CH}_{2} \mathrm{Cl}_{2}$ and a saturated solution of $\mathrm{NH}_{4} \mathrm{PF}_{6}$ in water was added dropwise. The precipitate was then subjected to a flash column chromatography 
(silica gel, $\mathrm{CH}_{2} \mathrm{Cl}_{2}$ pure to $\mathrm{CH}_{2} \mathrm{Cl}_{2} / \mathrm{MeOH}$ : 9/1) to obtain the desired yellow powder of Ir3' $(0.080 \mathrm{~g}, 89 \%)$.

${ }^{1}$ HNMR (400 MHz, CDCl $): \delta_{\mathrm{H}} 8.68(\mathrm{~d}, \mathrm{~J}=8.17 \mathrm{~Hz}, 2 \mathrm{H}), 8.59(\mathrm{~s}, 2 \mathrm{H}), 8.49$ (s, 2H), $8.21(\mathrm{~m}$, 2H), 8.19 (dd, J = 1.43, $5.07 \mathrm{~Hz}, 2 \mathrm{H}), 7.83$ (dd, J = 5.07, $8.23 \mathrm{~Hz}, 2 \mathrm{H}), 7.62$ (dd, J= 1.58, 8.08 $\mathrm{Hz}, 2 \mathrm{H}), 7.54(\mathrm{~m}, 4 \mathrm{H}), 6.45$ (dd, J = 3.15, $8.08 \mathrm{~Hz}, 2 \mathrm{H}), 4.40(\mathrm{sex}, \mathrm{J}=7.09 \mathrm{~Hz}, 4 \mathrm{H}), 3.93$ (s, $6 \mathrm{H}), 1.39(\mathrm{~m}, 6 \mathrm{H})$.

${ }^{13}$ CNMR (100 MHz, MeOD): $\delta_{\mathrm{c}} 167.72,167.18,166.72,163.99,163.49,157.25,157.07$, $150.67,149.85,149.69,146.37,143.45,140.09$, 139.86, 139.70, 131.97, 131.87, 128.95, 126.92 , 125.73, 123.67, 119.67, 68.46, 67.86, 66.75, 66.69, 65.70, 64.27, 62.67, 61.00, 63.30, $52.11,29.68,15.17,15.06,14.43,14.16$.

${ }^{31}$ P NMR (162 MHz, MeOD): $\delta_{\mathrm{p}}-144.82$ (hept, J = $713 \mathrm{~Hz}$ ).

MALDI-TOF: m/z: Calculated for: 939.2134 [M]+, Found: $939.2179[\mathrm{M}]+, \Delta=4.8$ ppm.

\section{Compound Ir3}

Ir3' $(0.063 \mathrm{~g}, 0.058 \mathrm{mmol})$ was dissolved in mixture of $\mathrm{H}_{2} \mathrm{O} / \mathrm{MeOH}(17 \mathrm{ml}, 8 / 1)$ and degassed with bubbling argon while sonicating (20 min). Then $\mathrm{LiOH}(0.011 \mathrm{~g}, 0.46 \mathrm{mmol})$ was added. The resulting solution was stirred under argon and shielded from light during $32 \mathrm{~h}$. After cooling to room temperature, the $\mathrm{MeOH}$ was evaporated and the $\mathrm{pH}$ was adjusted to around 7 with $\mathrm{NH}_{4} \mathrm{Cl}$ (saturated aqueous solution). The precipitate was filtered, washed with $\mathrm{H}_{2} \mathrm{O}, \mathrm{Et}_{2} \mathrm{O}$. The residue was dissolved in a minimum amount of $\mathrm{MeOH}$ and precipitated with a $\mathrm{Bu}_{4} \mathrm{NPF}_{6}$ methanolic solution. Addition of an excess $\mathrm{CH}_{3} \mathrm{CN}$ entailed more precipitation. The solid was filtered, washed with $\mathrm{CH}_{3} \mathrm{CN}$ (5 ml), dried and collected as a yellow powder of $\mathbf{I r 3}(0.026 \mathrm{~g}$, $44 \%)$.

${ }^{1}$ HNMR (400 MHz, CDCl3 + ع MeOD-d4): $\delta_{\mathrm{H}} 8.53$ (dd, J = 1.26, 8.26 Hz, 2H), 8.48 (s, 2H), $8.34(\mathrm{~m}, 2 \mathrm{H}), 8.10(\mathrm{~m}, 2 \mathrm{H}), 8.07(\mathrm{~s}, 2 \mathrm{H}), 7.72(\mathrm{dd}, \mathrm{J}=5.25,8.36 \mathrm{~Hz}, 2 \mathrm{H}), 7.41(\mathrm{~m}, 2 \mathrm{H}), 7.21$ $(\mathrm{m}, 4 \mathrm{H}), 6.31(\mathrm{~d}, \mathrm{~J}=7.97 \mathrm{~Hz}, 2 \mathrm{H})$.

${ }^{13}$ CNMR (100 MHz, CDCl3 + $\varepsilon$ MeOD-d4): $\delta_{\mathrm{c}}$ 152.52, 149.86, 142.59, 140.51, 133.06, $130.08,128.41,127.68,125.05,121.69,53.33$.

${ }^{31}$ P NMR (162 MHz, CDCl3 + $\varepsilon$ MeOD-d4): $\delta_{\mathrm{p}}$ not enough signal to measure.

MALDI-TOF: m/z: Calculated for: 855.1195 [M]+, Found: $855.1163[\mathrm{M}]+, \Delta=3.7$ ppm. 


\section{Compound 4}

To a gun dried tube under argon atmosphere, complex $3(0.370 \mathrm{~g}, 0.565 \mathrm{mmol})$ was dissolved in $4 \mathrm{ml}$ of degassed $\mathrm{CH}_{2} \mathrm{Cl}_{2}$. Then, $\mathrm{N}$-bromosuccinimide $(0.089 \mathrm{~g}, 0.500 \mathrm{mmol})$ was added at $0^{\circ} \mathrm{C}$, in one portion and the tube was sealed under argon. The mixture was warmed at room temperature and stirred overnight. Then, the reaction was poured into $\mathrm{EtOH}$, the volume was reduced under vacuum. The crude product was precipitated with a saturated aqueous solution of $\mathrm{NH}_{4} \mathrm{PF}_{6}$ and extracted three times with $\mathrm{CH}_{2} \mathrm{Cl}_{2}$ to remove the excess of $\mathrm{NH}_{4} \mathrm{PF}_{6}$. The organic layer was dried, concentrated and purified by flash column chromatography (silica gel, $\mathrm{CH}_{2} \mathrm{Cl}_{2}$ /petroleum ether gradient, from $1 / 1$ to pure $\mathrm{CH}_{2} \mathrm{Cl}_{2}$ ). As mentioned in the body of the text, we could not isolate pure $\mathbf{4}$ and the resulting mixture of $\mathbf{3 , 4}$ and bis-brominated compound was directly involved in the next step.

\section{Compound Ir4'}

Compound 4 (0.055 g, $0.075 \mathrm{mmol}), 5(0.064 \mathrm{~g}, 0.112 \mathrm{mmol})$, potassium carbonate $(0.027 \mathrm{~g}$, $0.200 \mathrm{mmol}$ ) were placed in an oven dried tube under argon. Then, a mixture of Toluene/EtOH/ $\mathrm{H}_{2} \mathrm{O}(8 \mathrm{ml}, 10 / 2 / 1)$ was added and the resulting solution was freed from oxygen by argon bubbling while sonicating (30 $\mathrm{min}) . \mathrm{Pd}\left(\mathrm{PPh}_{3}\right)_{4}(0.009 \mathrm{~g}, 0.008 \mathrm{mmol})$ was added and the solution was heated at $100^{\circ} \mathrm{C}$ for $24 \mathrm{~h}$. After cooling to room temperature, $\mathrm{CH}_{2} \mathrm{Cl}_{2}$, water and $\mathrm{NH}_{4} \mathrm{PF}_{6}$ (saturated aqueous solution) were added and the organic layer was washed with water and dried over anhydrous $\mathrm{MgSO}_{4}$. The concentrated crude was then purified by flash column chromatography (silica gel, $\mathrm{CH}_{2} \mathrm{Cl}_{2}$ to $\mathrm{CH}_{2} \mathrm{Cl}_{2}$ /acetone, 99/1) to afford the title product Ir4' as yellow powder $(0.048 \mathrm{~g}, 53 \%)$.

${ }^{1}$ HNMR (400 MHz, CDCl $): \delta_{\mathrm{H}} 8.67(\mathrm{~d}, \mathrm{~J}=8.15 \mathrm{~Hz}, 2 \mathrm{H}), 8.15(\mathrm{dt}, \mathrm{J}=1.29,7.81 \mathrm{~Hz}, 2 \mathrm{H})$, 8.02 (d br, J = 3.70 Hz, 1H), 8.00 (s br, 1H), 7.94 (m, 2H), 7.88 (m, 3H), 7.86 (s br, 2H), 7.78 $(\mathrm{dq}, \mathrm{J}=1.29,7.08 \mathrm{~Hz}, 2 \mathrm{H}), 7.70(\mathrm{~d} \mathrm{br}, \mathrm{J}=7.70 \mathrm{~Hz}, 1 \mathrm{H}), 7.53(\mathrm{~m}, 4 \mathrm{H}), 7.43(\mathrm{~m}, 2 \mathrm{H}), 7.16(\mathrm{~d}$ br, J = 8.42 Hz, 3H), 7.10 (s br, 2H), 7.08 (s br, 3H), 7.05 (m, 2H), 6.94 (t, J = 7.49 Hz, 1H), $6.39(\mathrm{~d}, \mathrm{~J}=7.84 \mathrm{~Hz}, 1 \mathrm{H}), 6.33(\mathrm{~d}, \mathrm{~J}=7.62 \mathrm{~Hz}, 1 \mathrm{H}), 1.58$ (s, 18H).

${ }^{13}$ CNMR (101 MHz, CDCl $)$ ): $\delta_{\mathrm{c}} 167.77,167.51,165.36,155.81,150.62,150.17,149.95$, $149.66,148.84,148.72$, 145.16, 144.17, 143.51, 139.92, 138.20, 137.72, 134.76, 132.28, $131.75,130.84,129.40,128.11,127.70,126.39$, 126.26, 125.46, 124.84, 123.71, 123.52, $123.41,122.99,122.81,122.56,119.64,80.77,28.25$. 


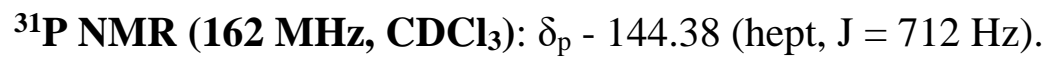

MALDI-TOF: m/z: Calculated for: 1098.3698 [M]+, Found: $1098.3746[\mathrm{M}]+, \Delta=4.4$ ppm.

\section{Compound Ir4}

Ir4' (0.047 g, $0.038 \mathrm{mmol})$ was dissolved in mixture of THF/MeOH $(9 \mathrm{ml}, 8 / 1)$ and degassed by bubbling argon while sonicating (20 min). Then $2 \mathrm{ml}$ of $\mathrm{LiOH}$ in methanolic solution (1M) was added. The resulting solution was refluxed under argon and shielded from light during $32 \mathrm{~h}$. After cooling to room temperature, the $\mathrm{pH}$ was adjusted to around 5 with $\mathrm{AcOH}(1 \mathrm{M})$. The mixture was extracted with $\mathrm{CH}_{2} \mathrm{Cl}_{2}$ twice and dried over $\mathrm{MgSO}_{4}$. After removal of the solvent, $\mathrm{MeOH}$ and then $\mathrm{NH}_{4} \mathrm{PF}_{6}$ (saturated aqueous solution) were added to form a precipitate that was filtered, washed with $\mathrm{Et}_{2} \mathrm{O}$ and water and finally dried. The desired product was obtained as yellow powder Ir4 (0.034 g, 81\%).

${ }^{1}$ HNMR (400 MHz, CDCl 3 + $\boldsymbol{\varepsilon}$ MeOD-d $\left.{ }^{4}\right): \delta_{H} 8.55$ (dd, J = 3.02, $\left.8.40 \mathrm{~Hz}, 2 \mathrm{H}\right), 8.11(\mathrm{dq}=\mathrm{J}=$ 1.44, $7.92 \mathrm{~Hz}, 2 \mathrm{H}), 8.05$ (s br, 1H), 8.03 (d, J = 4.56 Hz, 1H), 7.99 (dd, J = 1.07, $5.50 \mathrm{~Hz}, 1 \mathrm{H}$ ), $7.94(\mathrm{~d} \mathrm{br}, 8.58 \mathrm{~Hz}, 1 \mathrm{H}), 7.86(\mathrm{~m}, 1 \mathrm{H}), 7.82(\mathrm{~d}, \mathrm{~J}=8.85 \mathrm{~Hz}, 4 \mathrm{H}), 7.76(\mathrm{~m}, 2 \mathrm{H}), 7.68(\mathrm{~m}, 1 \mathrm{H})$, 7.45 (m, 6H), $7.12(\mathrm{dd}, \mathrm{J}=1.88,8.04 \mathrm{~Hz}, 1 \mathrm{H}), 7.07$ (d br, J = $8.58 \mathrm{~Hz}, 2 \mathrm{H}), 7.00$ (m, 7H), 6.90 $(\mathrm{dt}, \mathrm{J}=1.21,7.51 \mathrm{~Hz}, 1 \mathrm{H}), 6.31(\mathrm{~d}, \mathrm{~J}=7.91 \mathrm{~Hz}, 1 \mathrm{H}), 6.27(\mathrm{~d}, \mathrm{~J}=7.10 \mathrm{~Hz}, 1 \mathrm{H})$.

${ }^{13}$ CNMR (101 MHz, $\mathbf{C D C l}_{3}+\varepsilon$ MeOD-d $\left.{ }^{4}\right): \delta_{\mathrm{c}} 173.80,167.86,155.92,155.80,155.78,150.97$, $150.85,150.72,149.73,149.42,149.38,148.43,144.60,144.04,143.63,143.42,143.30$, $142.93,139.65,138.53,132.16,131.71,130.55,130.62,129.56,128.51,127.41,125.58$, $125.11,124.71,123.44,123.31,123.25,123.07,122.67,120.03$.

${ }^{31}$ P NMR (162 MHz, CDCl 3 + $\varepsilon$ MeOD-d4): $\delta_{\mathrm{p}}-144.53$ (hept, J = 708 Hz).

MALDI-TOF: m/z: Calculated for $986.2446[\mathrm{M}]+$, Found: $986.2404[\mathrm{M}]+, \Delta=4.3$ ppm.

\section{Computational details}

All calculations for Ir 1-4 and Ru4 were performed with Density Functional Theory (DFT). The geometries of the singlet ground-state $\left({ }^{1} \mathrm{GS}\right)$, of the lowest triplet ES $\left(\mathrm{T}_{1}\right)$, as well as of the reduced radical species were optimized using the B3LYP hybrid exchange-correlation functional,[71, 72] in combination with the 6-31G(d) atomic basis set for all atoms but the metal centers. Relativistic effects were included for the $\mathrm{Ru}$ and (Ir) atoms by using the ecp-mwb28(60) pseudopotentials.[73] The nature of the stationary points was confirmed by computing 
the Hessian at the same level of theory. The UV-Vis absorption characteristics were obtained by calculating vertical singlet excitation energies using TD-B3LYP at the ${ }^{1} \mathrm{GS}$ geometries. The phosphorescence emission spectra were simulated on the basis of $\triangle$ SCF-B3LYP calculations at the $\mathrm{T}_{1}$ optimized geometries. Both the TD-B3LYP and the $\triangle$ SCF-B3LYP calculations took into account solvation effects within the PCM framework (chloroform was used as a solvent, linearresponse approach was applied for the TD-DFT part).[74] All calculations were carried out with the Gaussian09 program package.[75]

\section{Conflict of interest}

There are no conflict of interest to declare.

Acknowledgement: D. E. thanks funding from Internal Funds KU Leuven. This work used the computational resources of the CCIPL installed in Nantes. Région des Pays de la Loire is gratefully acknowledged for the financial support of these researches through the project NiOPhotoCat and the program LUMOMAT.

\section{References}

[1] Flamigni L, Barbieri A, Sabatini C, Ventura B, Barigelletti F. Photochemistry and Photophysics of Coordination Compounds: Iridium. Top. Curr. Chem. 2007: 143-203.

[2] Costa RD, Ortí E, Bolink HJ, Monti F, Accorsi G, Armaroli N. Luminescent Ionic Transition-Metal Complexes for Light-Emitting Electrochemical Cells. Angew. Chem. Int. Ed. 2012; 51: 8178-211.

[3] Colombo MG, Hauser A, Güdel HU. Competition between ligand centered and charge transfer lowest excited states in bis cyclometalated Rh3+ and Ir3+ complexes. Top. Curr. Chem. 1994: 143-71. [4] Dixon IM, Collin J-P, Sauvage J-P, Flamigni L, Encinas S, Barigelletti F. A family of luminescent coordination compounds: iridium() polyimine complexes. Chem. Soc.Rev. 2000; 29: 385-91.

[5] Wong W-Y, Ho C-L. Heavy metal organometallic electrophosphors derived from multi-component chromophores. Coord. Chem. Rev. 2009; 253: 1709-58.

[6] Lo KK-W, Tsang KH-K, Sze K-S, Chung C-K, Lee TK-M, Zhang KY, Hui W-K, Li C-K, Lau JS$\mathrm{Y}, \mathrm{Ng}$ DC-M, Zhu N. Non-covalent binding of luminescent transition metal polypyridine complexes to avidin, indole-binding proteins and estrogen receptors. Coord. Chem. Rev. 2007; 251: 2292-310.

[7] You Y, Cho S, Nam W. Cyclometalated Iridium(III) Complexes for Phosphorescence Sensing of Biological Metal Ions. Inorganic Chemistry 2014; 53: 1804-15.

[8] Li SP-Y, Yip AM-H, Liu H-W, Lo KK-W. Installing an additional emission quenching pathway in the design of iridium(III)-based phosphorogenic biomaterials for bioorthogonal labelling and imaging. Biomaterials 2016; 103: 305-13. 
[9] Zhang KY, Li SP-Y, Zhu N, Or IW-S, Cheung MS-H, Lam Y-W, Lo KK-W. Structure, Photophysical and Electrochemical Properties, Biomolecular Interactions, and Intracellular Uptake of Luminescent Cyclometalated Iridium(III) Dipyridoquinoxaline Complexes. Inorg. Chem. 2010; 49: 2530-40.

[10] Ma D-L, He H-Z, Zhong H-J, Lin S, Chan DS-H, Wang L, Lee SM-Y, Leung C-H, Wong C-Y. Visualization of Zn2+ Ions in Live Zebrafish Using a Luminescent Iridium(III) Chemosensor. ACS Appl. Mater. Interfaces 2014; 6: 14008-15.

[11] Medina-Castillo AL, Fernandez-Sanchez JF, Klein C, Nazeeruddin MK, Segura-Carretero A, Fernandez-Gutierrez A, Grätzel M, Spichiger-Keller UE. Engineering of efficient phosphorescent iridium cationic complex for developing oxygen-sensitive polymeric and nanostructured films. Analyst 2007; 132: 929-36.

[12] Köse ME, Crutchley RJ, DeRosa MC, Ananthakrishnan N, Reynolds JR, Schanze KS. Morphology and Oxygen Sensor Response of Luminescent Ir-Labeled Poly(dimethylsiloxane)/Polystyrene Polymer Blend Films. Langmuir 2005; 21: 8255-62.

[13] Demas JN, DeGraff BA. Design and applications of highly luminescent transition metal complexes. Anal. Chem. 1991; 63: 829A-37A.

[14] Zhang P, Wang M, Na Y, Li X, Jiang Y, Sun L. Homogeneous photocatalytic production of hydrogen from water by a bioinspired [Fe2S2] catalyst with high turnover numbers. Dalton Trans. 2010; 39: 1204-06.

[15] Yuan Y-J, Yu Z-T, Chen X-Y, Zhang J-Y, Zou Z-G. Visible-Light-Driven H2 Generation from Water and $\mathrm{CO} 2$ Conversion by Using a Zwitterionic Cyclometalated Iridium(III) Complex. Chem. Eur. J. 2011; 17: 12891-95, S91/1-S91/15.

[16] Cline ED, Adamson SE, Bernhard S. Homogeneous Catalytic System for Photoinduced Hydrogen Production Utilizing Iridium and Rhodium Complexes. Inorganic Chemistry 2008; 47: 10378-88.

[17] Goldsmith JI, Hudson WR, Lowry MS, Anderson TH, Bernhard S. Discovery and HighThroughput Screening of Heteroleptic Iridium Complexes for Photoinduced Hydrogen Production. J. Am. Chem. Soc. 2005; 127: 7502-10.

[18] Mayo EI, Kilsa K, Tirrell T, Djurovich PI, Tamayo A, Thompson ME, Lewis NS, Gray HB. Cyclometalated iridium(III)-sensitized titanium dioxide solar cells. Photochem. Photobiol. Sci. 2006; 5: 871-73.

[19] Baranoff E, Yum J-H, Jung I, Vulcano R, Gratzel M, Nazeeruddin MK. Cyclometallated iridium complexes as sensitizers for dye-sensitized solar cells. Chemistry - An Asian Journal 2010; 5: 496-99.

[20] Sinopoli A, Wood CJ, Gibson EA, Elliott PIP. Hybrid Cyclometalated Iridium Coumarin Complex as a Sensitiser of Both n- and p-Type DSSCs. Eur. J. Inorg. Chem. 2016; 2016: 2887-90.

[21] Yuan Y-J, Zhang J-Y, Yu Z-T, Feng J-Y, Luo W-J, Ye J-H, Zou Z-G. Impact of Ligand Modification on Hydrogen Photogeneration and Light-Harvesting Applications Using Cyclometalated Iridium Complexes. Inorg. Chem. 2012; 51: 4123-33.

[22] Erten-Ela S, Ocakoglu K. Iridium dimer complex for dye sensitized solar cells using electrolyte combinations with different ionic liquids. Materials Science in Semiconductor Processing 2014; 27: $532-40$.

[23] Gennari M, Legalite F, Zhang L, Pellegrin Y, Blart E, Fortage J, Brown AM, Deronzier A, Collomb M-N, Boujtita M, Jacquemin D, Hammarstrom L, Odobel F. Long-Lived Charge Separated State in NiO-Based p-Type Dye-Sensitized Solar Cells with Simple Cyclometalated Iridium Complexes. J Phys. Chem Lett 2014; 5: 2254-58.

[24] Sinopoli A, Wood CJ, Gibson EA, Elliott PIP. New cyclometalated iridium(III) dye chromophore complexes for n-type dye-sensitized solar cells. Inorganica Chimica Acta 2017; 457: 81-89.

[25] Sinopoli A, Wood CJ, Gibson EA, Elliott PIP. New cyclometalated iridium(III) dye chromophore complexes for p-type dye-sensitized solar cells. Dyes Pigments 2017; 140: 269-77.

[26] Dragonetti C, Valore A, Colombo A, Righetto S, Trifiletti V. Simple novel cyclometallated iridium complexes for potential application in dye-sensitized solar cells. Inorg. Chim. Acta 2012; 388: 163-67.

[27] Telleria A, Kohlrausch BSEC, Duarte RdC, Rodembusch FS, Dupont J, Freixa Z, Santos MJL. Synthesis and Characterization of Diethylphosphonate and Carboxylate-appended Iridium Complexes for the Application on Dye-Sensitized Solar Cells. Chem. Select 2016; 1: 2842-48. 
[28] Shinpuku Y, Inui F, Nakai M, Nakabayashi Y. Synthesis and characterization of novel cyclometalated iridium(III) complexes for nanocrystalline $\mathrm{TiO}_{2}$-based dye-sensitized solar cells. J. Photochem. Photobiol. 2011; 222: 203-09.

[29] Ning Z, Zhang Q, Wu W, Tian H. Novel iridium complex with carboxyl pyridyl ligand for dyesensitized solar cells: High fluorescence intensity, high electron injection efficiency? J. Organomet. Chem. 2009; 694: 2705-11.

[30] Matt B, Xiang X, Kaledin AL, Han N, Moussa J, Amouri H, Alves S, Hill CL, Lian T, Musaev DG, Izzet G, Proust A. Long lived charge separation in iridium(iii)-photosensitized polyoxometalates: synthesis, photophysical and computational studies of organometallic-redox tunable oxide assemblies. Chem. Sci. 2013; 4: 1737-45.

[31] Flamigni L, Collin J-P, Sauvage J-P. Iridium Terpyridine Complexes as Functional Assembling Units in Arrays for the Conversion of Light Energy. Acc. Chem. Res. 2008; 41: 857-71.

[32] Odobel F, Pellegrin Y. Recent advances in the sensitization of wide-band-gap nanostructured ptype semiconductors. Photovoltaic and photocatalytic applications. J. Phys. Chem. Lett. 2013; 4: 255164.

[33] Odobel F, Pellegrin Y, Gibson EA, Hagfeldt A, Smeigh AL, Hammarström L. Recent advances and future directions to optimize the performances of p-type dye-sensitized solar cells. Coord. Chem. Rev. 2012; 256: 2414-23.

[34] Bonomo M, Dini D. Nanostructured p-Type Semiconductor Electrodes and Photoelectrochemistry of Their Reduction Processes. Energies 2016; 9: 373.

[35] Colvin MT, Ricks AB, Scott AM, Co DT, Wasielewski MR. Intersystem Crossing Involving Strongly Spin Exchange-Coupled Radical Ion Pairs in Donor-bridge-Acceptor Molecules. J. Phys. Chem. A 2012; 116: 1923-30.

[36] Wasielewski MR, Johnson DG, Svec WA, Kersey KM, Minsek DW. Achieving high quantum yield charge separation in porphyrin-containing donor-acceptor molecules at $10 \mathrm{~K}$. J. Am. Chem. Soc. 1988; 110: 7219-21.

[37] Wiederrecht GP, Svec WA, Wasielewski MR, Galili T, Levanon H. Novel Mechanism for Triplet State Formation in Short Distance Covalently Linked Radical Ion Pairs. J. Am. Chem. Soc. 2000; 122: 9715-22.

[38] Higashino T, Yamada T, Yamamoto M, Furube A, Tkachenko NV, Miura T, Kobori Y, Jono R, Yamashita K, Imahori H. Remarkable Dependence of the Final Charge Separation Efficiency on the Donor-Acceptor Interaction in Photoinduced Electron Transfer. Angew. Chem. Int. Ed. 2016; 55: 62933.

[39] van Dijk SI, Groen CP, Hartl F, Brouwer AM, Verhoeven JW. Long-Lived Triplet State Charge Separation in Novel Piperidine-Bridged Donor-Acceptor Systems. J. Am. Chem. Soc. 1996; 118: 842532.

[40] Hviid L, Bouwman WG, Paddon-Row MN, van Ramesdonk HJ, Verhoeven JW, Brouwer AM. Spin control of the lifetime of an intramolecular charge-transfer excited state. Photochem. Photobiol. Sciences 2003; 2: 995-1001.

[41] Mori Y, Sakaguchi Y, Hayashi H. Spin Effects on Decay Dynamics of Charge-Separated States Generated by Photoinduced Electron Transfer in Zinc Porphyrin-Naphthalenediimide Dyads. J. Phys. Chem. A 2002; 106: 4453-67.

[42] Yukie M, Yoshio S, Hisaharu H. Spin Chemical Approach towards Long-Lived Charge-Separated States Generated by Photoinduced Intramolecular Electron Transfer in a Donor-Bridge-Acceptor System. Bull. Chem. Soc. Jpn. 2001; 74: 293-304.

[43] Geiss B, Lambert C. A small cationic donor-acceptor iridium complex with a long-lived chargeseparated state. Chem. Commun. 2009: 1670-72.

[44] Baranoff E, Dixon IM, Collin J-P, Sauvage J-P, Ventura B, Flamigni L. Dyads Containing Iridium(III) Bis-terpyridine as Photoactive Center: Synthesis and Electron Transfer Study. Inorg. Chem. 2004; 43: 3057-66.

[45] Flamigni L, Marconi G, Dixon IM, Collin J-P, Sauvage J-P. Switching of Electron- to EnergyTransfer by Selective Excitation of Different Chromophores in Arrays Based on Porphyrins and a Polypyridyl Iridium Complex. J. Phys. Chem. B 2002; 106: 6663-71. 
[46] Hanss D, Freys JC, Bernardinelli G, Wenger OS. Cyclometalated Iridium(III) Complexes as Photosensitizers for Long-Range Electron Transfer: Occurrence of a Coulomb Barrier. Eur. J. Inorg. Chem. 2009: 4850-59.

[47] Ji Z, Natu G, Huang Z, Kokhan O, Zhang X, Wu Y. Synthesis, Photophysics, and Photovoltaic Studies of Ruthenium Cyclometalated Complexes as Sensitizers for p-Type NiO Dye-Sensitized Solar Cells. J. Phys. Chem. C 2012; 116: 16854-63.

[48] Ji Z, Natu G, Wu Y. Cyclometalated Ruthenium Sensitizers Bearing a Triphenylamino Group for p-Type NiO Dye-Sensitized Solar Cells. ACS Appl. Mater. Interfaces 2013; 5: 8641-48.

[49] Ji Z, Wu Y. Photoinduced Electron Transfer Dynamics of Cyclometalated Ruthenium (II)Naphthalenediimide Dyad at NiO Photocathode. J. Phys. Chem. C 2013; 117: 18315-24.

[50] Wood CJ, Robson KCD, Elliott PIP, Berlinguette CP, Gibson EA. Novel triphenylamine-modified ruthenium(ii) terpyridine complexes for nickel oxide-based cathodic dye-sensitized solar cells. RSC Adv. 2014; 4: 5782-91.

[51] Le Lagadec R, Alexandrova L, Estevez H, Pfeffer M, Laurinavicius V, Razumiene J, Ryabov AD. Bis-ruthena(III)cycles $[\mathrm{Ru}(\mathrm{C} \cap \mathrm{N}) 2(\mathrm{~N} \cap \mathrm{N})] \mathrm{PF} 6$ as low-potential mediators for PQQ alcohol dehydrogenase $(\mathrm{C} \cap \mathrm{N}=2$-phenylpyridinato or 4-(2-tolyl)-pyridinato, $\mathrm{N} \cap \mathrm{N}=$ bpy or phen). European Journal of Inorganic Chemistry 2006: 2735-38.

[52] Ryabov AD, Ceron-Camacho R, Saavedra-Diaz O, Denardo MA, Ghosh A, Le Lagadec R, Collins TJ. TAML Activator-Based Amperometric Analytical Devices as Alternatives to Peroxidase Biosensors. Anal. Chem. 2012; 84: 9096-100.

[53] Gibson EA, Smeigh AL, Le Pleux L, Hammarström L, Odobel F, Boschloo G, Hagfeldt A. Cobalt Polypyridyl-Based Electrolytes for p-Type Dye-Sensitized Solar Cells. J. Phys. Chem. C 2011; 115: 9772-79.

[54] Sinopoli A, Black FA, Wood CJ, Gibson EA, Elliott PIP. Investigation of a new bis(carboxylate)triazole-based anchoring ligand for dye solar cell chromophore complexes. Dalton Transactions 2017; 46: 1520-30.

[55] Daeneke T, Yu Z, Lee GP, Fu D, Duffy NW, Makuta S, Tachibana Y, Spiccia L, Mishra A, Bäuerle P, Bach U. Dominating Energy Losses in NiO p-Type Dye-Sensitized Solar Cells. Adv. Energy Mater. 2015; 5: 10.1002/aenm.201401387.

[56] Favereau L, Pellegrin Y, Hirsch L, Renaud A, Planchat A, Blart E, Louarn G, Cario L, Jobic S, Boujtita M, Odobel F. Engineering Processes at the Interface of p-Semiconductor for Enhancing the Open Circuit Voltage in p-Type Dye-Sensitized Solar Cells. Adv. Energy Mater. 2017; 7: doi: 10.1002/aenm.201601776.

[57] Ahn SY, Ko MJ, Ha Y. The heteroleptic complexes containing 2,3-diphenylquinoline derivatives as phosphorescent materials. J. Phys. Chem. Solids 2008; 69: 1320-24.

[58] Zhang W, Hu J, Young DJ, Hor TSA. Phosphorescent Emitters from Natural Products: CinchonineDerived Iridium(III) Complexes. Organometallics 2011; 30: 2137-43.

[59] Edkins RM, Wriglesworth A, Fucke K, Bettington SL, Beeby A. The synthesis and photophysics of tris-heteroleptic cyclometalated iridium complexes. Dalton Transactions 2011; 40: 9672-78.

[60] Yi XY, Zhang CS, Guo S, Ma J, Zhao JZ. Strongly emissive long-lived (IL)-I-3 excited state of coumarins in cyclometalated Ir(III) complexes used as triplet photosensitizers and application in triplettriplet annihilation upconversion. Dalton Transactions 2014; 43: 1672-83.

[61] Ji ZQ, He MF, Huang ZJ, Ozkan U, Wu YY. Photostable p-Type Dye-Sensitized Photoelectrochemical Cells for Water Reduction. J. Am. Chem. Soc. 2013; 135: 11696-99.

[62] Fraysse S, Coudret C, Launay JP. One-pot palladium-catalysed synthesis of molecular wires. Tetrahedron Lett. 1998; 39: 7873-76.

[63] Fraysse S, Coudret C. Unexpected formation of a scrambled aryl-phosphine oxide under modified Sonogashira conditions. Tetrahedron Lett. 1999; 40: 9249-50.

[64] Weidelener M, Mishra A, Nattestad A, Powar S, Mozer AJ, Mena-Osteritz E, Cheng YB, Bach U, Bauerle P. Synthesis and characterization of perylene-bithiophene-triphenylamine triads: studies on the effect of alkyl-substitution in p-type $\mathrm{NiO}$ based photocathodes. J. Mater. Chem. 2012; 22: 7366-79.

[65] Flamigni L, Barbieri A, Sabatini C, Ventura B, Barigelletti F, Photochemistry and photophysics of coordination compounds: Iridium. In Photochemistry and Photophysics of Coordination Compounds Ii, Balzani, V.; Campagna, S., Eds. 2007; Vol. 281, pp 143-203. 
[66] Liu Z, Bian Z, Hao F, Nie D, Ding F, Chen Z, Huang C. Highly efficient, orange-red organic lightemitting diodes using a series of green-emission iridium complexes as hosts. Org. Electron. 2009; 10: 247-55.

[67] Swiderek K, Paneth P. Modeling excitation properties of iridium complexes. J. Phys. Org. Chem. 2009; 22: 845-56.

[68] Su Y, Kang L-H. Theoretical studies of ground and excited electronic states in a series of heteroleptic iridium complexes using density functional theory. Int. J. Quantum Chem. 2012; 112: 242228.

[69] Lowry MS, Goldsmith JI, Slinker JD, Rohl R, Pascal RA, Malliaras GG, Bernhard S. Single-Layer Electroluminescent Devices and Photoinduced Hydrogen Production from an Ionic Iridium(III) Complex. Chem. Mater. 2005; 17: 5712-19.

[70] Thoi VS, Kornienko N, Margarit CG, Yang P, Chang CJ. Visible-Light Photoredox Catalysis: Selective Reduction of Carbon Dioxide to Carbon Monoxide by a Nickel N-Heterocyclic CarbeneIsoquinoline Complex. J. Am. Chem. Soc. 2013; 135: 14413-24.

[71] Becke AD. DENSITY-FUNCTIONAL THERMOCHEMISTRY .3. THE ROLE OF EXACT EXCHANGE. J. Chem. Phys. 1993; 98: 5648-52.

[72] Lee CT, Yang WT, Parr RG. DEVELOPMENT OF THE COLLE-SALVETTI CORRELATIONENERGY FORMULA INTO A FUNCTIONAL OF THE ELECTRON-DENSITY. Phys. Rev. B 1988; 37: 785-89.

[73] Andrae D, Haussermann U, Dolg M, Stoll H, Preuss H. ENERGY-ADJUSTED ABINITIO PSEUDOPOTENTIALS FOR THE 2ND AND 3RD ROW TRANSITION-ELEMENTS. Theor. Chim. Acta 1990; 77: 123-41.

[74] Tomasi J, Mennucci B, Cammi R. Quantum mechanical continuum solvation models. Chem. Rev. 2005; 105: 2999-3093.

[75] Frisch GMJ. Gaussian 09, Revision A.1, Gaussian, Inc., Wallingford CT 2009. 